\title{
A Decisão Parcial sem Mérito e as suas Hipóteses
}

\author{
The Partial Decision without Merit and its Hypotheses
}

Vinicius Silva Lemos'

'Faculdade de Rondônia e União das Escolas Superiores de Rondônia - FARO e UNIRON, Brasil

\section{Resumo}

Este artigo aborda o estudo da complexidade objetiva do processo e a decisão parcial sem mérito, diante da impossibilidade de prosseguimento de parcela da jurisdição e a prolação de uma decisão extintiva, pelo teor do art. 354, parágrafo único do CPC. O intuito passa por entender os requisitos autorizantes específicos da decisão parcial sem mérito e a relação com as questões de fato específicos dos pressupostos processuais de cada capítulo e, por último, analisar cada hipótese específico de decisão parcial sem mérito.

Palavras-chave: Decisão Parcial; Processo Objetivamente Complexo; Extinção Parcial; Hipóteses

\begin{abstract}
This article discusses the study of the objective complexity of the process and the partial decision without merit, given the impossibility of pursuing a portion of the jurisdiction and the delivery of an extinguishing decision, by the content of art. 354, the sole paragraph of the CPC. The purpose is to understand the specific authorizing requirements of the partial decision without merit and the relationship with the de facto questions specific to the procedural presupposition of each chapter and, finally, to analyze each specific hypothesis of partial decision without merit.
\end{abstract}

Keywords: Partial decision; Objectively Complex Process; Partial Extinction; Hypotheses

\section{Introdução}

A jurisdição nasce a partir da iniciativa de um indivíduo em pleitear ao Estado a solução de um conflito e a concessão de um direito. Diante disso, nasce a necessidade da heterocomposição, da resposta jurisdicional ao pleito realizado.

O pedido de jurisdição detém uma divisão entre capítulos decisórios, com a divisão da procedimentalidade entre uma análise processual, com a relação sobre o cumprimento dos pressupostos processuais, e uma análise de mérito, com relação ao pedido realizado pelo autor daquela ação.

No entanto, a jurisdição pode ser plural, com a possibilidade, além da divisão básica de capítulos entre admissibilidade e mérito, de conter diversas relações jurídicas a serem resolvidas, dada a abertura para pluralidade de partes ou uma cumulação de pedidos realizados.

A prestação jurisdicional complexa em seu objeto do processo ocorre igualmente na sentença, quando o juízo resposta todos os pedidos realizados no processo, se a demanda for admissível, contudo 
diante da positivação dos arts. 354, parágrafo único e 356 do CPC é possível a decisão parcial, com o julgamento de parcela da jurisdição e a postergação do restante para a prolação de uma sentença que finda aquela fase do processo.

Logo, o CPC/2015 trabalha com a unicidade da sentença, mas permite uma decisão parcial, seja com resolução de mérito, seja sem resolução de mérito. O presente trabalho tem como objeto de estudo a decisão parcial sem mérito, diante da utilização do art. 354, parágrafo único do CPC, as suas possibilidades e hipóteses. Se a decisão parcial de mérito é importante para a cisão da demanda por jurisdição em capítulos desta, a decisão parcial sem mérito trabalha com a extinção de uma parcela sem conseguir chegar no final da própria jurisdição com a resposta almejada pelas partes.

Dessa maneira, o recorte do presente estudo é o foco da decisão parcial sem mérito e os seus requisitos autorizantes específicos e, posteriormente, a análise das hipóteses de ocorrência da cisão cognitiva e processual extintiva, com o enfrentamento da bibliografia sobre o assunto e a dedução dos resultados pesquisados.

\section{A Possibilidade de Complexidade Objetiva do Processo no Exercício da Jurisdição}

Diante do pleito e o exercício da jurisdição, uma demanda, quanto ao seu objeto, pode ser simples ou complexa.

A simples será uma só pretensão deduzida que tem como partes um autor e um réu. O transcorrer do procedimento está envolto sempre a uma unidade, a decorrer, a priori, uma processualística mais simples.

Ao contrário, a demanda objetivamente complexa é aquela ação que contém pluralidade de pedidos ou de partes, com uma série de pretensões a serem expostas ao mesmo tempo, impondo uma necessidade ao juízo responder todos os pleitos ali existentes para o exercício da jurisdição, tornando o objeto do processo uma complexidade de relações jurídicas a serem resolvidas.

Em sua base, o processo civil é voltado, em sua maioria construtiva, a organizar, primordialmente, o processo de maneira simples em seu objeto, a construir uma evolução gradual para o entendimento da simplicidade e, somente após, com alguns dispositivos autorizantes de menção à complexidade e a pluralidade de resoluções jurídicas em mesmo processo, como o litisconsórcio, intervenção de terceiros ou cumulação de pedidos.

Primeiro entende-se o processo como uma relação entre duas partes - autor e réu - e um pedido, constituindo uma relação jurídica a ser respondida e solucionada, depois o ordenamento possibilita uma série de intersecções que este processo se adapte à complexidade de relações jurídicas, como diversas partes ou diversos pedidos.

Nessa conjuntura, é complexo objetivamente o processo que enseja a prolação de uma sentença que contenha mais de uma decisão interna em seu mérito1. Obviamente que a cumulação de pedidos enseja essa pluralidade de decisões no ato decisório, tornando-se complexo, no entanto, há a possibilidade de um só pedido também tornar a sentença objetivamente complexa quando houver a possibilidade de decomposição do pedido.

1 Barbosa Moreira foca a sua conceituação de processo complexo objetivamente a partir do prisma da sentença ser complexa: "Numa primeira aproximação, poderiam assim definir-se as sentenças cujo dispositivo contém mais de uma decisão. Também seria possível caracterizar a sentença objetivamente complexa aquela que se compõe de mais de um capítulo.” BARBOSA MOREIRA, José Carlos. Sentença objetivamente complexa, trânsito em julgado e rescindibilidade. Revista Dialética de Direito Processual. Vol. 45, São Paulo: Dialética, dez/2006. p. 54. Já Dinamarco expõe a mesma complexidade através do objeto do processo, mas com resultado idêntico a Barbosa Moreira: "A complexidade do objeto do processo, seja em virtude da cumulação de pedidos na demanda de vida pelo autor, seja pela superveniência de pedidos (reconvenção, etc,), repercute necessariamente na sentença de mérito mediante a necessária a presença de tantos capítulos quantos forem os pedidos postos dia do juiz à espera do julgamento.” DINAMARCO, Cândido Rangel. Capítulos de sentença. $3^{\text {a } . ~ e d . ~ S a ̃ o ~ P a u l o: ~ M a l h e i r o s, ~ 2008 . ~ p . ~} 42$. 
A complexidade objetiva do processo inicia-se na cumulação do próprio ato de demandar, seja pela pluralidade de pedidos, seja na pluralidade de partes.

Uma vez que o autor cumula pedidos em sua petição inicial, não será somente uma pretensão deduzida em juízo, ao inverso, serão quantas forem pleiteadas, cada qual com a exigência de resposta sobre o acolhimento ou não, bem como sobre a sua admissibilidade específica. Essa cumulação de pedidos pode ser em momento ulterior, pelo réu, por exemplo, também tornando o processo complexo em seu objeto em eventual reconvenção ou pedido contraposto.

A pluralidade de partes - fora o litisconsórcio unitário² - enseja também uma pluralidade de relações jurídicas em juízo, com cada qual representando um objeto diverso e, por isso, necessário ser considerado complexo para a construção dos argumentos das partes, produção de provas, atos processuais até a sentença e sua recorribilidade.

\subsection{A positivação da cisão cognitiva e a decisão parcial no CPC/2015}

No CPC/2015, houve a positivação de cada uma dessas possibilidades de julgamento parcial arts. 354, parágrafo único e 356 do CPC, com a cindibilidade da demanda e da sua concepção decisória, porém seria necessária a positivação para tanto? Na concepção do ordenamento anterior, não havia nada sobre a disposição de tal cisão, com a utilização do que Liebman defendia de que qualquer cindibilidade iria em sentido contrário à teoria da unicidade da sentença e somente seria possível com a autorização legal ${ }^{3}$.

A doutrina já se debruçava, no ordenamento anterior, ainda que timidamente, sobre o tema, com a defesa de que o processo objetivamente complexo já possibilitava essas cisões, independentemente de autorização legal.

Depois de duas alterações legais, primeiro com a inclusão do $\S 6^{\circ}$ ao art. 273 do $\mathrm{CPC} / 73$, pela Lei $n^{\circ}$ 10.444/02 e depois a alteração da conceituação de sentença, com a redação do art. 162, $\S 1^{\circ}$ do CPC/73 modificada pela Lei n⿳o 11.232/05, o estudo da cisão cognitiva e cisão de decisões, quebrando a unicidade da sentença, com a possibilidade de prolação de sentenças parciais, passou a ser alvo de maior aprofundamento e, consequentemente, de mais controvérsias, apesar de não ser um assunto que tenha se esgotado, com resistência pela sua ausência de norma autorizante e dificuldade de compreensão, o que fez a jurisprudência não caminhar nesse sentido, ao menos diante do ordenamento anterior revogado.

Dessa maneira, de modo geral, a cisão cognitiva e o fracionamento decisório existente no CPC/2015, estão dispostos no art. 354, parágrafo único e no art. 356, ambos do CPC.

A primeira hipótese trata de uma cisão sobre as questões de admissibilidade do processo. Cada pedido de um processo objetivamente complexo detém uma admissibilidade própria e peculiar, com o dever do juízo em analisar cada questão sobre o cumprimento devido de cada pressuposto. Quando proceder essa análise e, porventura, um dos pressupostos não estiver presente, sem a possibilidade de sanabilidade, o juízo deve decidir pela extinção, dada a inviabilidade do prosseguimento do processo.

Todavia, se essa ausência de preenchimento dos pressupostos for de um vício que somente impacta parcela do processo, o juízo deve decidir pela extinção parcial, extinguindo aquele pedido ou excluindo uma parte que não deveria ali constar, sem atingir a totalidade do processo, realizando uma autêntica cisão cognitiva.

De mesmo modo, numa segunda hipótese, quando analisar que um dos pedidos do processo está apto a ser respondido antes dos demais também existentes no pleito do autor, o juízo deve, desde logo,

2 "um só pedido e uma só decisão, embora endereçada simultaneamente a dois, a três ou a vários.” DINAMARCO, Cândido Rangel. Capítulos de sentença. 3a. ed. São Paulo: Malheiros, 2008. p. 74.

3 Sobre a unicidade e a necessidade de norma para a sua excecionalidade, na visão de Liebman, destacada por Dinamarco: $\square$ tal é o princípio da unidade estrutural da sentença, que só pode ser contrariado quando uma específica norma de direito o autorizar (Liebman). $\square$ DINAMARCO, Cândido Rangel. Instituições de direito processual civil. Vol. III. $3^{\mathrm{a}}$. ed. São Paulo: Malheiros, 2003. p. 700/701. 
decidir o que é possível, cindindo o processo e prosseguindo com a parcela que não for possível decidir naquele momento.

Se no ordenamento processual anterior não havia tal previsão positivada, com a necessidade de construção doutrinária para tanto, com a defesa de que a complexidade objetiva já autorizaria essa cisão em situações processuais que os fatos e ocorrências concretas possibilitassem essas cisões desse porte, o CPC/2015 possibilita positivadamente essas cisões, vislumbrando que a análise das questões podem levar a cognição ser cindida, tanto nas questões de admissibilidade quanto no próprio objeto litigioso do processo, em ambos com a viabilidade de julgamento de modo parcial.

No entanto, importante diferenciar as cisões, uma vez que, apesar de levarem a cognições e decisões parciais ${ }^{4}$, são motivadas por diretrizes totalmente diversas, não sendo correto enquadrá-las como idênticas, o que importa em diferenciá-las para entender a espécie de cisão que ocorre em cada situação.

\section{A Decisão Parcial sem Mérito}

Se a demanda nasce de um ato postulatório, evidentemente que existirão pressupostos processuais para a admissibilidade deste ato e do processo como um todo. Todo ato postulatório proporciona um juízo de admissibilidade ${ }^{5}$, uma análise sobre o preenchimento pelo autor de todos os requisitos pertinentes para que a jurisdição possa ser prestada em sua plenitude.

Desse modo, antes da análise sobre o que se pleiteou, há a análise sobre o cumprimento dos pressupostos para que haja um pedido, uma demanda. Se o juízo entender pelo cumprimento de todos os pressupostos processuais para a demanda proposta pelo autor, a análise de mérito será realizada quando a cognição judicial sobre todos os pontos for possível e exauriente, contudo, de modo inverso, caso não seja preenchido algum dos pressupostos, o juízo deve possibilitar a sanabilidade do vício, se sanável, ou extinguir o processo pela presença desse vício, se insanável.

De toda maneira, não há ato postulatório analisado em seu mérito sem um juízo prévio de admissibilidade ${ }^{6}$.

Como exposto, a sentença é o ato processual que encerra a fase de cognição de primeiro grau, e, diante de seu conteúdo, pode versar sobre a jurisdição em torno do acolhimento, ou não, do pleito da demanda ou sobre a existência de um vício de caráter intransponível ao processo, numa das questões preliminares, por falta de pressuposto processual ${ }^{7}$.

O ato sentencial é o cerne da busca pela jurisdição pelo autor e a resposta do poder estatal para aquele pedido, seja imediato, seja mediato. $\mathrm{O}$ intuito deve ser resolver o conflito, com a aplicação do melhor direito ao caso em concreto, julgando nos limites do que foi pleiteado pelo autor, com todo

4 Se a cognição pode ser dividida mediante os capítulos decisórios, a processualística pode dividir as decisões entre totais e parciais. No CPC/73: SCARPARO, Eduardo Kochenborger. Sentenças parciais? Considerações a partir de reforma do art. 162, §1º, do CPC. Revista de Processo. n. 148, Ano 32, p. 153-168, São Paulo: Ed. RT, Jun/2007. No CPC/2015: DIDIER JR., Fredie. Comentários ao art. 485. In: CABRAL, Antônio do Passo; CRAMER, Ronaldo (Coord.). Comentários ao novo Código de Processo Civil. Rio de Janeiro: Forense, 2015.

5 BARBOSA MOREIRA, José Carlos. O novo processo civil brasileiro. 20. ed. Rio de Janeiro: Forense, 2000. p. 116.

6 Sobre admissibilidade e mérito, utilizando da explicação recursal para todo ato postulatório: "Como todo ato postulatório, a impugnação da decisão judicial por meio de recurso submete-se a exame sob dois ângulos diversos. Primeiro, cumpre verificar se estão satisfeitas as condições impostas pela lei para que se possa apreciar o conteúdo da postulação (juízo de admissibilidade); depois, e desde que o resultado tenha sido positivo - isto é, que o recurso seja admissível-, cumpre decidir a matéria impugnada através deste, para acolher a impugnação, caso fundada, ou rejeitá-la, caso infundada (juizo de mérito).” BARBOSA MOREIRA, José Carlos. O novo processo civil brasileiro. 20. ed. Rio de Janeiro: Forense, 2000. p. 116.

$7 \quad$ Sobre o conceito de sentença abarcar qualquer resultado, ainda que sem mérito, importando, para tanto, somente que encerre uma fase processual: "Pois sentença é o ato que põe fim a um módulo processual. Assim, nos casos em que o processo se desenvolva em um só módulo (processo de conhecimento ou processo de execução), a sentença será o ato de encerramento do procedimento em contraditório (ou, como se costuma dizer no jargão forense, o ato que põe fim ao processo).” CÂMARA. Alexandre Freitas. O novo processo civil brasileiro. 4⿳ạ. ed. São Paulo: Atlas, 2018. p. 262 
o efetivo contraditório ou somente aplicando o direito quando não houver um conflito, mas houver jurisdição.

\section{Essa é a visão perfeita processualmente para uma demandå .}

No entanto, na análise das questões preliminares, nos pressupostos processuais de admissibilidade do processo, o juízo ao constatar um vício deve decidir, caso não seja possível saná-lo, por extinguir o processo, mesmo que não haja uma efetiva resposta ao jurisdicionado quanto ao que foi pedido ou pleiteado. A sentença, portanto, será pela constatação de um vício e, dessa maneira, sem análise de mérito.

Evidentemente que se o vício constatado for sanável ${ }^{9}$, o juízo deve possibilitar que o autor o faça, com um prazo específico para tanto, no intuito de que o processo não se esvaia por um vício que possa ser corrigido. Não há motivos para que o juízo decida pela extinção sem análise de mérito se o vício for corrigível e sanável.

Essa é a manifestação do princípio da primazia ao julgamento do mérito ${ }^{10}$, com a possibilidade de priorizar-se, processualmente, o julgamento do pedido do autor, do objeto em litígio.

Por obviedade, ultrapassado o prazo concedido pelo juízo para o autor para a devida sanabilidade do vício, sem nenhuma manifestação ou com insuficiência desta, deve-se proceder com a prolação de uma sentença sem análise do mérito, justamente pela constatação da ocorrência de uma questão preliminar que impede o julgamento meritório, inviabilizando a cognição judicial exauriente sobre o pedido do autor.

O juízo não realizará a completude das cognições na demanda, estacionando, processualmente, na cognição das questões preliminares ${ }^{11}$, extinguindo o processo ${ }^{12}$.

8 "toda demanda deduzida em juízo como ato inicial de um processo traz em si a soma de duas pretensões, ou seja, de duas aspirações que o demandante apresenta ao juiz em busca de reconhecimento e satisfação.” DINAMARCO, Cândido Rangel. Capítulos de sentença. $3^{\text {a }}$. ed. São Paulo: Malheiros, 2008. p. 38.

$9 \quad$ Sobre sanabilidade e primazia ao julgamento de mérito: "O art. 352 do CPC prevê, justamente, a determinação do juiz para corrigir as irregularidades e os vícios sanáveis, razão de ser da fase saneadora, a fim de permitir a organização do processo, com vistas a um julgamento de mérito. O art. 139, IX, do CPC dispõe que ao juiz incumbe determinar o suprimento de pressupostos processuais e o saneamento de outros vícios processuais. Trata-se de um dos poderes-deveres do juiz. (...) A norma fundamental da primazia do julgamento do mérito, prevista no art. $4^{\circ}$ do CPC, assegura tal prorrogação.” ARAÚUO, Luciano Vianna. Comentário ao art. 352. Novo código de processo civil comentado - Tomo II (art. 318 ao art. 770 ). Orgs: RIBEIRO, Sergio Luiz Almeida; GOUVEIA FILHO, Roberto Pinheiro Campos; PANTALEÃO, Izabel Cristina; GOUVEIA, Lucio Grassi de. São Paulo: Lualri, 2017. p. 87.

10 "Consolida-se, aí, um princípio fundamental: o de que se deve dar primazia à resolução de mérito (e à produção do resultado satisfativo do direito) sobre o reconhecimento de nulidades ou de outros obstáculos à produção do resultado normal do processo civil. Eis, aí, portanto, o princípio da primazia da resolução do mérito.” CÂMARA, Alexandre Freitas. O princípio da primazia da resolução do mérito e o novo código de processo civil. Revista de Direito da ADVOCEF. Ano XI no 21, São Paulo: Advocef, nov/2015. p. 16; "Realmente concretizado estará sendo o princípio se a razoável duração do processo levar em conta não só o tempo até a sentença, mas a duração integral do caminho a ser percorrido pelo autor até que se obtenha integralmente a satisfação de seu direito.” ALVIM, Teresa Arruda; CONCEIÇÃO, Maria Lúcia Lins; RIBEIRO, Leonardo Ferres da Silva; MELLO, Rogério Licastro Torres de. Primeiros comentários ao novo código de processo civil. São Paulo: Ed. RT. 2015. p. 61.

11 Há uma relação de subordinação e, por isso, somente quando o subordinante for ultrapassado: BARBOSA MOREIRA, José Carlos. Questões prejudiciais e questões preliminares. Direito processual civil (ensaios e pareceres). Rio de Janeiro: Borsoi, 1971. p. 76.

12 "O art. 485 do CPC/2015 dispõe sobre a decisão terminativa, que proclama a ausência de algum requisito processual, impedindo, de modo peremptório, a resolução do mérito (art. 487 do CPC/2015; sobre os requisitos processuais, cf. comentário infra). A prolação de uma decisão dessa natureza é medida excepcional, só tomada quando não for possível corrigir o vício (cf. art. 317 do CPC/2015) ou proferir decisão de mérito em favor daquele a quem aproveita a prolação de decisão terminativa (cf. art. 488 do CPC/2015). Os requisitos processuais, porém, cumprem função importantíssima: sua ausência (e não incidindo o disposto nos arts. 317 ou 488 do CPC/2015) impõe a prolação de decisão terminativa, evitando-se, com isso, que o processo se desenvolva inutilmente.” MEDINA, José Miguel Garcia. Novo código de processo

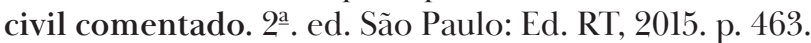


Todavia, num processo complexo objetivamente, o juízo de admissibilidade também será partido em cada complexidade que a própria demanda impõe. Se há uma cumulação de pedidos, cada pedido detém uma admissibilidade própria, pela própria autonomia inerente a cada capítulo do processo. De mesmo modo ocorre quando há uma pluralidade de partes no processo, com uma cumulação subjetiva, com uma série de relações jurídicas entre os diversos autores ou réu, ou ambos. Cada uma dessas relações detém uma admissibilidade própria, pela autonomia dos capítulos de cada relação.

Se num processo complexo objetivamente um dos pontos da demanda detém a sua admissibilidade e outro ponto esbarra na existência de um vício, dada a autonomia dos capítulos do processo, é plenamente possível que uma parcela do processo seja extinta e a outra prossiga, numa bipartição cognitiva sobre a admissibilidade, dada a existência e percepção pelo juízo da viabilidade de cindir o processo, diante da impossibilidade de continuidade de parcela desta e preenchimento dos pressupostos no restante.

Dessa maneira, se a presença de um vício intransponível no processo impõe a necessidade da prolação de uma sentença sem resolução de mérito ${ }^{13}$, nos moldes que o art. 354 do CPC, há a possibilidade que o vício não alcance a integralidade do processo, recaindo somente sobre uma parte deste, o juízo deve prolatar uma decisão que extingue somente parcela do processo, sem analisar o que se pleiteou no tocante aquele ponto de mérito, não o processo como um todo.

Diante disso, o art. 354, parágrafo único do CPC, possibilita que o juízo profira decisão interlocutória parcial sem resolução de mérito, extinguindo parte da demanda, quando houver a ocorrência das hipóteses dos arts. 485 e 487, II e III do CPC (mesmo que nesses últimos dispositivos falem de mérito, está enquadrado na hipótese de extinção, ainda que não seja, propriamente dita).

Não há que se falar, nesse momento, de uma sentença, pelo fato de que parcela do processo tem prosseguimento, enquanto, somente uma parcela será extinta.

Com isso, nasce a decisão parcial sem mérito, com a extinção da demanda em parte ${ }^{14}$.

Logo, se o art. 354, parágrafo único do CPC autoriza que parcela do processo seja extinta, autoriza a prolação de uma decisão interlocutória parcial sem resolução de mérito e não uma alteração na conceituação de sentença, tampouco uma sentença parcial.

Dessa maneira, é totalmente possível que um processo contenha a extinção de parte dela por uma decisão interlocutória que aplique o teor dos arts. 485 e 487, II e III do CPC.

\section{As Hipóteses de Extinção Parcial e da Decisão Parcial sem Mérito}

$\mathrm{O}$ art. 354 do CPC determina que diante de uma análise preliminar sobre o preenchimento, ou não, dos pressupostos processuais ${ }^{15}$, se o juízo entender que algum destes não foi corretamente

13 Sobre a sentença de extinção: "A sentença de extinção do processo é sempre de natureza declaratória: nela se declara, expressamente, extinto o processo, e, de modo implícito ou explícito, a inadmissibilidade da tutela jurisdicional.” MARQUES, José Frederico. Manual de direito processual civil. Vol. II, 2a․ ed., Rio de Janeiro: Saraiva, 1976. p. 150.

14 "A chamada "extinção parcial”: A maior novidade redacional contida nos arts. 354 e 356 diz respeito à expressa possibilidade de fracionamento das fases processuais. O parágrafo único, do art. 354, prevê a extinção de apenas parcela do processo, caso em que será impugnável por agravo de instrumento.” ARAÚJO, José Henrique Mouta. Comentário ao art. 354. Novo código de processo civil comentado - Tomo II (art. 318 ao art. 770). Orgs: RIBEIRO, Sergio Luiz Almeida; GOUVEIA FILHO, Roberto Pinheiro Campos; PANTALEÃO, Izabel Cristina; GOUVEIA, Lucio Grassi de. São Paulo: Lualri, 2017. p. 89 .

15 Sobre os mitos dos pressupostos processuais: Há, ainda, cinco "mitos" sobre os pressupostos processuais que devem ser combatidos. Nem toda falta de pressuposto processual leva ao juízo de admissibilidade do processo. Basta pensar na incompetência, cujo reconhecimento leva à remessa dos autos ao juízo competente, e no impedimento ou suspeição, cujo reconhecimento leva à remessa dos autos ao juiz substituto (art. 146, § 5.․, CPC). Nem toda falta de pressuposto processual pode ser conhecida de ofício. Basta pensar na incompetência relativa (art. 64, § 1.․o; art. 337, § 5. . , CPC), na existência de convenção de arbitragem (art. 337, § 5.‥ CPC) e na falta de autorização do cônjuge para a propositura da ação real imobiliária (art. 1.650, Código Civil). Nem toda falta de pressuposto processual pode ser conhecida a qualquer tempo ou grau de jurisdição. Basta pensar na alegação de convenção de arbitragem e de falta de citação; se o réu contestar e não as alegar, haverá preclusão. Nem toda falta de pressuposto processual é defeito que não pode ser corrigido. Ao contrário, a 
preenchido, tampouco seja sanável, ou se for, após a oportunidade para sanabilidade sem resposta do autor, deve-se prolatar uma sentença de extinção, justamente por falta de admissibilidade ${ }^{16}$.

No entanto, se a falta desse pressuposto impactar somente parcela de um processo objetivamente complexo, a extinção proposta não será a do caput do art. 354 do CPC, mas a do parágrafo único, de modo parcial, com a continuidade do processo em relação a uma parcela que cumpriu todos os pressupostos de admissibilidade.

Todas essas possibilidades de extinção representam obstáculos para que o juízo possa julgar o mérito, seja pela falta de admissibilidade, seja por outros fatos, como morte do autor, abandono ou desistência. Essas possibilidades impedem o julgamento de mérito, em determinadas situações, contudo se forem impactantes somente sobre parcela da demanda, serão tidas como uma extinção parcial.

Sobre especificadamente o abandono ${ }^{17}$ e a desídia da parte ${ }^{18}$, ou seja, os incisos II e III do art. 485 do CPC, (o processo ficar parado durante mais de 1 ano por negligência das partes; por não promover os atos e as diligências que lhe incumbir, o autor abandonar a causa por mais de 30 dias) ${ }^{19}$, não há a possibilidade de decisão parcial, uma vez esses atos ou omissões do autor ${ }^{20}$ maculariam o processo como um todo, possibilitando a prolação de uma sentença sem mérito ${ }^{21}$, não de uma decisão parcial. Evidentemente que o juízo pode determinar emendas ou correções específicas de cada pedido ou relação jurídica, contudo a omissão pertinente a esse ponto, diante dessas hipóteses, levariam a decisão parcial sem mérito por outro motivo, pela incorreção ou vício anterior, não a própria desídia.

Para tanto, pertinente o entendimento de que cada hipótese descrita nesses artigos supracitados pode servir de subsídio para a prolação de uma sentença extintiva sem mérito, contudo é importante

regra é a de que se deve aplicar, ao exame dos pressupostos processuais, o sistema de invalidades do CPC, segundo o qual se deve buscar, sempre, a correção do defeito processual, mesmo que se trate da falta de um pressuposto processual. Nem toda falta de um pressuposto processual impede a decisão de mérito. O art. 488 do CPC é claro ao determinar que, mesmo havendo um defeito no processo, o juiz não deve levá-lo em consideração, se a causa puder ser julgada no mérito em favor daquele que se beneficiaria com a decisão de inadmissibilidade. Assim, se a petição for inepta em razão da existência de um pedido indeterminado (art. 330, § 1. , II, CPC), mas a demanda puder ser julgada improcedente, o juiz deve ignorar o defeito e julgar o mérito." DIDIER JR., Fredie. Comentários ao art. 485. In: CABRAL, Antônio do Passo; CRAMER, Ronaldo (Coord.). Comentários ao novo Código de Processo Civil. Rio de Janeiro: Forense, 2015. p. 681.

16 Sobre a inviabilidade do mérito se a decisão for pela inadmissibilidade por falta de pressupostos processuais: "Há dependência, também, do capítulo portador do julgamento de mérito, em relação ao que decide sobre admissibilidade desse julgamento: não se chega àquele, caso o julgamento contido neste seja de teor negativo.” DINAMARCO, Cândido Rangel. Capítulos de sentença. 3 a ed. São Paulo: Malheiros, 2008. p. 44.

17 O abandono somente se configura com a devida intimação para manifestação do autor, pessoalmente: “determina a intimação pessoal da parte para suprir a falta no prazo de quarenta e oito horas e somente após tal intimação é que poderá o juiz extinguir o processo por inércia do autor. No prazo de quarenta e oito horas poderá o autor não só suprir a falta, como também justificar o motivo pelo qual não praticou o ato." SOUZA, Paulo Roberto Pereira de. Abandono da causa. Revista de Processo. Vol. 24, Ano 6, p. 117-136, São Paulo: Ed. RT, Out/Dez/1981. p. 125.

18 O autor deve controlar o seu direito material e ter a qualidade decisiva sobre a sua atuação: "Isso significa que o litigante tem full control sobre o seu direito material e as suas respectivas garantias processuais e, outrossim, bem revela o poder da parte de livre escolha para o exercício ou não exercício destas prerrogativas.” TUCCI, José Roberto Cruz e. Comentários ao novo código de processo civil: artigos 485 ao 538. Coords: MARINONI, Luiz Guilherme; ARENHART, Sérgio Cruz; MITIDIERO, Daniel. São Paulo: Ed. RT, 2016. p. 39.

19 "O inciso III, aliás, se distingue do inciso II na medida em que naquele a omissão se refere a atos de diligências específicas que constituem ônus do autor, como ocorre com a citação. Daí a exigência de que haja prazo específico em curso imposto ao autor." FREIRE, Alexandre; RAMOS NETO, Newton Pereira. Comentário ao art. 485. STRECK, Lenio. Comentários ao código de processo civil. 11ª . ed. São Paulo: Saraiva, 2016. p. 700.

20 A omissão ou abandono do autor deverá ser condizente com o transcorrer da demanda e a sua essencialidade, sem ser por qualquer motivo para sua extinção. Algum prazo interlocutório, ao não ser cumprido, pode gerar somente a preclusão daquele momento, sem prejuízo à demanda como um todo. "De salientar-se, no entanto, que em algumas hipóteses a omissão do demandante afigura-se completamente irrelevante para o prosseguimento do processo. (...) A inércia, nesta hipótese, simplesmente torna prejudicada a diligência e o processo segue o seu curso, em detrimento do direito do próprio autor." TUCCI, José Roberto Cruz e. Comentários ao novo código de processo civil: artigos 485 ao 538. Coords: MARINONI, Luiz Guilherme; ARENHART, Sérgio Cruz; MITIDIERO, Daniel. São Paulo: Ed. RT, 2016. p. 47.

21 Súmula no. 240 do STJ: A extinção do processo, por abandono da causa pelo autor, depende de requerimento do réu. 
o enfrentamento de cada hipótese para ciência se cabe ou não a prolação de uma decisão parcial sem mérito.

\subsection{0 indeferimento parcial da inicial}

Ao receber a petição inicial, o juízo deve realizar uma análise perfunctória sobre a peça que inicia a demanda, com a verificação preliminar da presença dos pressupostos processuais inerentes à proposição Nesse momento, por essa análise, há diferentes consequências processuais para o andamento da demanda, dependendo do resultado da análise do juízo.

Se dessa análise sobrevier o resultado mais esperado, o mais perfeito, diante de uma inicial com todas as informações e pressupostos preenchidos, será dado o deferimento da inicial e o devido prosseguimento, com a determinação da citação do réu. Se algum dos pressupostos processuais ou requisitos da inicial estiverem lacunosos, é possível o aditamento ou emenda da inicial para que realizese a complementação ou correção de eventual vício.

O intuito de eventual pedido de aditamento ou correção provém da realização pelo autor da diligência ou providência faltante, para o posterior deferimento da inicial, dada a impossibilidade direta de prosseguir pela existência de algum vício sanável. Com a intimação do autor para adequar o vício ou falta de requisito, tendo este um prazo de quinze dias para manifestar-se e, cumprindo tal determinação, o juízo defere a inicial, com o prosseguimento do processo ${ }^{22}$.

Por outro lado, caso não seja possível o deferimento da inicial, ou concedido o prazo para adequação e correção sem nenhuma manifestação, o juízo deve indeferir a peça inicial, prolatando uma sentença sem analisar o mérito, extinguindo, desde logo, o processo ${ }^{23}$.

A petição inicial é um dos pressupostos processuais, afinal para que se postule em juízo necessita de um peticionamento válido para tanto, se houver vícios na petição inicial, naturalmente, há um vício que deve ser corrigido para a tramitação regular do processo. O próprio art. 330 do CPC delineia em quais as possibilidades que o juízo deve indeferir a inicial, listando-as: for inepta; a parte for manifestamente ilegítima; o autor carecer de interesse processual; não atendidas as prescrições dos arts. 106 e 321.

Em qualquer uma dessas hipóteses é possível, pelo juízo, o indeferimento da inicial ${ }^{24}$.

\footnotetext{
22 "Estando em termos a petição inicial (...) ou já tendo sido supridas as falhas ou corrigidos os defeitos e irregularidades (...), o juiz deferirá o requerimento de citação do réu." BARBOSA MOREIRA, José Carlos. O novo processo civil brasileiro. $20^{\circ}$. ed. Rio de Janeiro: Forense, 2000. p. 25.

23 No tocante ao indeferimento da inicial, este, se total ou parcial, deve ser no início da demanda, com a análise perfunctória, mediante o ato postulatório inicial, com os subsídios concedidos pelo autor. Todavia, não é limitado que o vício que pode motivar o indeferimento da inicial nessa análise preliminar seja somente desta fase, se o vício somente for percebido posteriormente, a decisão - total ou parcial - será possível, contudo não por indeferimento da inicial, mas igualmente sem mérito: "O indeferimento da petição inicial somente ocorre no início do processo: só há indeferimento liminar antes da ouvida do réu. Após a citação, o juiz não mais poderá indeferir a petição inicial, de resto já admitida, devendo, se vier a acolher alguma alegação do réu, extinguir o feito por outro motivo (NERY JR.; NERY, 2012, p. 647; Figueira JR., 2001, p. 162-163). A inépcia, por exemplo, pode ser reconhecida a qualquer tempo, mesmo após a contestação, mas, nesse caso, não implicará indeferimento da petição, e, sim, extinção do processo sem análise do mérito com base no art. 485, IV, CPC." DIDIER JR., Fredie. Comentários ao art. 485. In: CABRAL, Antônio do Passo; CRAMER, Ronaldo (Coord.). Comentários ao novo Código de Processo Civil. Rio de Janeiro: Forense, 2015. p. 675.

24 Barbosa Moreira separava o indeferimento em ordem formal, o de inadmissibilidade da ação e o indeferimento em motivo de mérito. A distinção era por causa das formalidades e pressupostos da própria petição, no primeiro caso, da carência de ação, no segundo, e da possibilidade de analisar a prescrição e decadência, no último. Sobre este último, o julgamento foi para a improcedência liminar do pedido, o que não será enquadrado como indeferimento (e não já era a partir do art. 285-A do CPC/83). Sobre a inadmissibilidade da ação, seria a falta de condição da ação, o que era uma visão sobre a existência destas no processo, numa teoria eclética da ação, o que, a nossa entender, não foi recepcionada pelo novel ordenamento, sendo estas insertas aos pressupostos processuais.” BARBOSA MOREIRA, José Carlos. O novo processo civil brasileiro. $20^{\circ}$. ed. Rio de Janeiro: Forense, 2000. p. $23 / 24$.
} 
No entanto, a questão pertinente será se a inicial pode ser indeferida de modo parcial ${ }^{25}$, gerando, portanto, uma decisão parcial sem resolução de mérito. Obviamente essa decisão parcial somente seria possível se houver um processo objetivamente complexo, com a possibilidade de cisão cognitiva e fracionamento decisório, nessa situação, sem resolução de mérito.

Nessa hipótese, o juízo deve deferir uma parcela da inicial ou da matéria ali inserta e, consequentemente, indeferir outra parcela, com um deferimento parcial e, também um indeferimento parcial, com uma extinção parcial da demanda, utilizando o art. 354, parágrafo único do CPC.

\section{O primeiro dos motivos para o indeferimento da inicial é a inépcia da inicial ${ }^{26}$.}

O próprio ordenamento estipula quando a inicial será inepta, no art. 330, § 1o do CPC: (i) lhe faltar pedido ou causa de pedir; (ii) o pedido for indeterminado, ressalvadas as hipóteses legais em que se permite o pedido genérico; (iii) da narração dos fatos não decorrer logicamente a conclusão; (iv) contiver pedidos incompatíveis entre si.

\section{A primeira hipótese divide-se em dois vícios diferentes: faltar pedido; ou faltar causa de pedir.}

Evidentemente que são vícios que impossibilitam a petição inicial de expressar a pretensão da demanda, contudo são vícios diferentes, apesar de ambos chegarem na mesma inviabilidade da petição ${ }^{27}$.

O primeiro vício consiste na ausência de pedido na lide, o que ensejaria uma petição inicial incompleta, com a necessidade de aditamento e, após intimação e eventual inércia do autor, o indeferimento da inicial. O pedido é fundamental ${ }^{28}$ para a própria existência da demanda e da inicial. O pedido consiste na delimitação da pretensão do autor em juízo, formulando de modo claro e conciso o bem jurídico almejado e, também, a espécie de decisão judicial que almeja.

Não há como uma inicial conter toda a sua causa de pedir ${ }^{29}$, com narrativa fático-jurídica sem alcançar uma conclusão lógica, um pedido final correspondente ao que se narrou. Sem esse pedido, não

25 Ainda no CPC/73, sobre o indeferimento da inicial, Barbosa Moreira já entendia como possível o indeferimento parcial, ou seja, uma decisão parcial sem mérito quando houvesse a cumulação: "O indeferimento pode ser total ou parcial. Será parcial, em havendo cumulação de pedidos, quando: a) só em relação a um ou a alguns dos pedidos cumulados ocorra qualquer das razões acima (...); b) o órgão judicial seja absolutamente incompetente quanto a um ou alguns dos pedidos; c) a própria cumulação seja impossível, porque aos dois ou mais pedidos deveriam corresponder tantos procedimentos diversos, mas o autor os formula em conjunto apesar de não os reduzir todos ao ordinário.” BARBOSA MOREIRA, José Carlos. O novo processo civil brasileiro. 20. ed. Rio de Janeiro: Forense, 2000. p. 25.

26 Nas palavras de Medina, a inépcia tem relação com a impossibilidade da petição veicular o que se pretende, com a identificação de sua condição para tanto, ou seja, mediante a interligação entre o pedido e uma narrativa de causa de pedir lógica: "Inepta é, literalmente, a petição não apta a veicular aquilo que se pede. Os requisitos processuais são funcionais (sobre função do ato processual, cf. comentário ao art. 188 do CPC/2015). A petição inicial realiza sua função quando o órgão jurisdicional depreende qual a prestação que deve realizar e o réu identifica aquilo em relação a que deve responder e se defender. É apta a petição que atinge esses objetivos (cf. STJ, AgRg no REsp 1346588/DF, rel. Min. Arnaldo Esteves Lima, Corte Especial, DJe 17.03.2014).” MEDINA, José Miguel Garcia. Novo código de processo civil comentado. $2^{a}$ ed. São Paulo: Ed. RT, 2015. p. 339. No mesmo sentido, Aurelli: Como se observa, não são quaisquer causas de vícios com relação a petição inicial que acarretam a inépcia. Veja-se que as causas de inépcia se referem exclusivamente a defeitos com relação ao pedido ou a causa de pedir." AURELLI, Arlete Inês. Comentário ao art. 330. Novo código de processo civil comentado - Tomo II (art. 318 ao art. 770). Orgs: RIBEIRO, Sergio Luiz Almeida; GOUVEIA FILHO, Roberto Pinheiro Campos; PANTALEÃO, Izabel Cristina; GOUVEIA, Lucio Grassi de. São Paulo: Lualri, 2017. p. 41.

27 Os dois em conjunto formam o objeto do processo: "Objeto do processo é o conjunto de todo o material lógico que o espírito do juiz capta e elabora de modo a saber: se julgará o mérito e como julgará.” DINAMARCO, Cândido Rangel. Instituições de direito processual civil. Vol. II 6a . ed. São Paulo: Malheiros, 2009. p. 182.

28 "Através da demanda, formula a parte um pedido, cujo teor determina o objeto do litígio e, consequentemente, o âmbito dentro do qual toca ao órgão judicial decidir a lide. (...) Ao ajuizar a demanda, pede o autor ao órgão judicial que tome determinada providência, declare a existência ou inexistência de uma relação jurídica, anule este ou aquele ato jurídico, condene o réu a pagar tal ou qual importância, a partir ou deixar de prato certo ato, etc.” BARBOSA MOREIRA, José Carlos. O novo processo civil brasileiro. 20․ ed. Rio de Janeiro: Forense, 2000. p. 10.

29 "O pedido tem um fundamento, que é a causa de pedir. E compõe-se de dois elementos: o provimento jurisdicional de determinada espécie (elemento força ou elemento condicionante), que pode ser declaratório, constitutivo, condenatório, executivo ou cautelar, e o bem jurídico-material que lhe é consequente (elemento efeito ou condicionado), ou seja, o chamado bem da vida. Empregamos o termo elemento no sentido da parte constitutiva do pedido, ou pretensão processual, 
há delimitação do mérito, não há o delinear do que o art. 141 do CPC $^{30}$ dispõe, sem vincular o juízo sobre os limites do objeto litigioso do processo.

Por outro lado, na análise do segundo vício da primeira hipótese de inépcia, cada pedido constante na inicial deve existir em relação a uma causa de pedir ${ }^{31}$, as razões jurídicas que constituem o direito que se pleiteia.

Desse modo, a causa de pedir está no plano do conjunto da narrativa fático-jurídica ${ }^{32}$ a ser feita pelo autor para basear os fatos e fundamentos do seu pedido ${ }^{33}$, com todo o delineamento da conjuntura das questões de fato e de direito ${ }^{34}$ inerente à pretensão posta ao juízo. Não há como uma inicial conter um pedido sem a construção narrativa da causa pelo qual é pertinente o pedido.

Este não pode existir sem o suporte do caso em concreto que o motiva ${ }^{35}$.

Sem constar um pedido na inicial, o juízo deve intimar a parte a fazê-lo corretamente e, de igual maneira, sobre a causa de pedir, se a inicial não contiver uma narrativa fático-jurídica, deve igualmente ter a intimação para esse esclarecimento e correção. Após a intimação para qualquer desses vícios e a manutenção da ausência, a inicial deve ser indeferida por inépcia.

Numa hipótese de uma inépcia parcial da petição inicial, apesar da existência de uma narrativa fático-jurídica de um ponto descrito sem um pedido correspondente ou vice-versa, um pedido realizado sem a causa de pedir exposta, o juízo defere a parcela da inicial que for possível e extingue a outra que não constar pedido ou causa de pedir. Todavia, é complexa essa hipótese de inépcia inicial, pelo fato de que a leitura da própria peça deve ser de modo minucioso para interligar cada causa de pedir a cada pedido e deixar clara essa interligação ou, no presente caso, a falta de interligação, pela ausência de pedido ou causa de pedir parcial.

Mas, é plenamente possível que a inépcia da inicial por falta de pedido ou causa de pedir seja de modo parcial, numa decisão parcial sem resolução de mérito, o deferimento do pedido que tiver em conformidade e a extinção daquele que continuar inepto.

e continuaremos acolhendo a denominação encontradiça nos autores, de objeto imediato e objeto mediato.” CARVALHO, Milton Paulo de. Do pedido no processo civil. Porto Alegre: Sérgio Antonio Fabris, 1992. p. 103

30 Como delimitar a demanda sem o pedido? "Chama-se pedido à manifestação processual da pretensão, isto é, o ato pelo qual o demandante declara, perante o juízo, o resultado que pretende obter com o processo. Incumbe ao autor, na petição inicial, deduzir tanto o pedido imediato (isto é, o provimento jurisdicional postulado) como o mediato (ou seja, o bem da vida que através do processo pretende obter)." CÂMARA. Alexandre Freitas. O novo processo civil brasileiro. $4^{\mathrm{a}}$. ed. São Paulo: Atlas, 2018. p. 188.

31 "Todo pedido tem uma causa. Identificar a causa petendié responder à pergunta: por que o autor pede tal providência? $\mathrm{Ou}$, em outras palavras: qual o fundamento de sua pretensão? Constitui-se a causa petendi do fato ou do conjunto de fatos a que o autor atribui a produção do efeito jurídico por ele visado.” BARBOSA MOREIRA, José Carlos. O novo processo civil brasileiro. $20^{\circ}$. ed. Rio de Janeiro: Forense, 2000. p. 15.

32 “em geral, o suporte fático é constituído por vários fatos. Esses fatos, que são transportados para o mundo jurídico por força da incidência, constituem o fato jurídico.” MELLO, Marcos Bernardes de. Teoria do fato jurídico. São Paulo: Saraiva, 2000. p. $54 / 55$.

33 "Anote- se que a petição inicial deve conter, como exigência formal mínima, além da explícita referência às partes, a indicação da causa de pedir e do pedido.” TUCCI, José Rogério Cruz e. Reflexões sobre a cumulação subsidiária de pedidos. Revista dos Tribunais (São Paulo). Vol. 786, p. 57-67, Abril/2001. p. 57.

34 Na visão de Tucci: “O objeto litigioso também alcança a causa de pedir.” TUCCI, José Rogério Cruz e. A causa petendi no processo civil. 3 a ed. São Paulo: Ed. RT, 2009. p. 131.

35 "a causa de pedir é elemento essencial da ação, pois revela a conexão entre o provimento jurisdicional pleiteado pelo autor e a pretensão por ele formulada." BEDAQUE, José Rogério dos Santos. Os elementos objetivos da demanda examinados a luz do contraditório. Causa de Pedir e Pedido no processo civil (questões polêmicas). Coords: TUCCI, José Rogério Cruz e; BEDAQUE, José Roberto dos Santos. São Paulo: Ed. RT, 2002. p. 29 /30. 
A segunda hipótese de inépcia será pela necessidade do pedido ser certo ${ }^{36} \mathrm{e}_{\text {determinado }}{ }^{37}$ e quando na inicial assim não for, ressalvados os casos excepcionais que a lei possibilita a forma indeterminada ${ }^{38-39}$, o juízo deve determinar a emenda para a adequação desse pedido e, no prazo estipulado, se o autor não emendar a inicial, com a determinação do pedido, a petição será inepta, culminando no indeferimento da mesma. Sem a determinação no pedido, não há como ter uma resposta jurisdicional sobre um pedido que seja genérico em hipóteses em que a lei assim não permite.

Se na inicial houver mais de um pedido e essa indeterminação for somente em um, a intimação para a emenda será específica para o pedido indeterminado ser corrigido, o que pode gerar, em caso de inércia do autor, a inépcia parcial e, consequentemente, o indeferimento parcial da petição inicial, com extinção sobre essa parcela do processo e continuidade das demais.

A terceira hipótese de inépcia consiste em falta de clareza e precisão na narrativa fático-jurídica, sem uma coerência lógica conclusiva do que ocorreu. Sem uma construção das questões de fato e de direito de modo entendível por quem fará a leitura, não há como deferir a inicial, com a necessidade, portanto, de emenda para esclarecimento e melhor construção da narrativa e, caso permaneça tal vício, com ou sem manifestação do autor, o juízo deve indeferir a inicial por inépcia.

A petição inicial deve conter a narrativa das questões de fato e de direito que culminem numa conclusão lógica de um caso em concreto que chegue numa subsunção de uma norma jurídica a ser utilizada para uma determinada pretensão ou pedido. Mas, pode essa inépcia ser parcial? Somente sobre algumas questões de fato? A resposta tende a ser positiva, com a visão de que se parte da narrativa consegue ser clara e coerente para um dos pedidos, diante da construção do entendimento de que o restante das questões de fato e direito que não foram expostas de modo claro são atinentes a outro pedido, com a possibilidade de separar as interligações entre cada pedido e cada causa de pedir narrada ${ }^{40}$.

Se for possível essa separação entre as questões de fato e a construção narrativa de cada pedido, a inépcia pode ser parcial, contudo se as questões de fato interliguem os pedidos na demanda, evidentemente que a inépcia parcial não será possível, com a necessidade da medição, pelo juízo, do impacto daquela construção mal realizada em cada pedido.

Todavia, é difícil entender que haja uma análise minuciosa e relacional entre uma determinada questão de fato estar bem delineada e outra questão não. Geralmente, as intimações para a emenda, nessa hipótese, são atinentes a uma melhora da descrição fática como um todo, mas cumpre salientar que o juízo deve cooperar para delinear o que está mal construído e não entendível, caso seja somente

36 "A certeza diz respeito à clareza do pedido, que deve ser expresso, não se admitindo pedido implícito [salvo as exceções legais], tanto no tocante ao tipo de provimento almejado (pedido imediato) como qual o bem da vida se espera obter (pedido mediato)." WAMBIER, Luiz Rodrigues; TALAMINI, Eduardo. Curso avançado de processo civil. vol. $2,5^{\mathrm{a}}$. ed. São Paulo: Ed. RT, 2016. p. 385.

37 Já a determinação refere-se aos limites daquilo que o autor pretende, demonstrando sua extensão. O pedido deve ser determinado, ou ao menos determinável.” WAMBIER, Luiz Rodrigues; TALAMINI, Eduardo. Curso avançado de processo civil. vol. 2, $5^{\text {a }}$ ed. São Paulo: Ed. RT, 2016. p. 385.

38 Sobre a conceituação de pedido genérico: "aquele em que não se determina o objeto mediato, sendo imprescindível a certeza e a determinação do objeto imediato” CARVALHO, Milton Paulo de. Do pedido no processo civil. Porto Alegre: Sérgio Antonio Fabris, 1992. p. 103.

$39 \quad$ No tocante aos pedidos genéricos e as suas possibilidades hipotéticas: "No entanto, o $§ 1^{\circ}$ do art. 324 do CPC prevê taxativamente que é lícito formular pedido genérico (certo, porém, determinável) em relação a pedido mediato (bem da vida pretendido), nas seguintes hipóteses (i) nas ações universais, se o autor não puder individuar os bens demandados, sendo um exemplo o caso de inventário no qual não se tem ciência da totalidade de bens que compõem o patrimônio, sendo por isso autorizada a formulação de pedido genérico; (ii) quando não for possível determinar, desde logo, as consequências do ato ou do fato, ocorrendo, por exemplo, nas ações de reparação de danos morais, nas quais, em regra, o autor faz uma estimativa de valores, mas fica a cargo do julgador o arbitramento do quantum indenizatório, levando em conta os elementos probatórios .da causa; (iii) quando a determinação do objeto ou do valor da condenação depender de ato que deva ser praticado pelo réu, sendo o caso, por exemplo, das ações de prestação de contas, cujo valor eventualmente devido a quem tem o direito de exigir somente será definido quando o réu realizar a prestação das contas.” THAMAY, Rennan Faria Kruger. Manual de direito processual civil. São Paulo: Saraiva, 2018. p. 264.

40 Nessa hipótese haveria uma independência sobre as questões de fato da demanda. 
uma parcela da construção fática, que pronunciamento judicial seja específico e cooperativo nesses moldes.

A quarta hipótese de inépcia está na existência de pedidos incompatíveis entre si, o que torna impossível a continuidade da demanda com essa complexidade. No entanto, para causar uma inépcia da inicial, os pedidos devem ser incompatíveis numa cumulação própria, aquela que visa a obtenção de procedência de todos os pedidos, o que não ocorre na cumulação imprópria, quando houver pleito pela alternatividade ${ }^{41}$, o que não levaria à inépcia, justamente pela incompatibilidade soar como a possibilidade um dos pedidos em detrimento do outro ${ }^{42}$.

Se dois pedidos ou mais forem incompatíveis, o juízo deve intimar o autor para adequar a demanda e escolher entre os pedidos, sob pena de indeferimento da inicial por inépcia. Mas, nesse caso, haveria a possibilidade de inépcia parcial e extinção parcial? Somente seria possível se o juízo optasse pelo deferimento da inicial por um pedido e a extinção de outro pedido, o que geraria um deferimento parcial e, consequentemente, um indeferimento parcial também, contudo essa escolha deve ficar a critério do autor, mediante intimação para que se proceda a escolha.

Há, também, uma nova hipótese de inépcia, na dicção do art. 330, §§ º e $3^{\circ}$ do CPC, quando a ação discorrer sobre revisão de obrigação de empréstimo, contém a necessidade de depósito, pelo autor, dos valores que entenda como incontroversos. $\mathrm{O}$ valor que o autor indicar como incontroverso em ação de discussão ou revisão de empréstimo deve ser depositado, se em única parcela as vencidas e, se ainda contiver na relação jurídica vincendas, deve continuar a ser depositado mensalmente.

Em ambos os casos, se houver descumprimento, em qualquer momento do processo importará em inépcia da inicial, caso seja instado a proceder o depósito faltante e quedar-se inerte. Se a demanda contiver outros pedidos, o juízo somente indeferirá a petição inicial quanto a esse pedido que versar sobre revisão de obrigação de empréstimo, mantendo o trâmite quanto aos demais pedidos, gerando, dessa maneira, uma decisão parcial sem mérito, com o indeferimento parcial da inicial.

Outros motivos de indeferimento da inicial são pela falta de interesse de agir ou legitimidade, contudo esse ponto será enfrentado quando for realizada a análise além da sua possibilidade na petição inicial, por ser um ponto específico e autônomo do art. 485, VI do CPC 43 .

A última hipótese de indeferimento da inicial consiste no atendimento de comandos judiciais para a emenda à inicial, seja para o advogado, de acordo com o art. 106 do CPC, regularizar a sua demanda em causa própria, sua inscrição, nome da sociedade de advocacia, endereço para recebimento das intimações, alteração de endereço, dentre outras obrigações da capacidade postulatória ${ }^{44}$.

Qualquer uma dessas irregularidades levará, no tocante ao advogado, ao indeferimento integral da inicial, com a extinção, sem a possibilidade de maneira parcial.

Outro ponto atinente a esse indeferimento, está no preenchimento dos requisitos da inicial previstos nos arts. 319 e 320 do CPC $^{45}$.

41 Para Assis, não existe cúmulo de ações no pedido alternativo, por ser um ou outro a ser considerado. "inexiste cúmulo de ações no pedido alternativo.” ASSIS, Araken de. Cumulação de ações. 4⿳a a ed. São Paulo, Ed. RT, 2002. p. 242.

42 Nessa hipótese considera-se uma cumulação de ações, o que leva ser uma ação a ser julgada ou outra: "alternativo, quando a parte requer a procedência de um ou de outro pedido, sendo as pretensões equivalentes, ou seja, a parte não manifesta preferência por quaisquer delas.” NOGUEIRA, Gláucia Assalin. O julgamento parcial: possibilidade de cisão do julgamento de mérito relativamente à parte incontroversa da demanda. São Paulo, SP, 2009. 191 p. Dissertação (Mestrado). Universidade de São Paulo. Programa de Pós-Graduação em Direito. p. 83.

43 A inclusão desse inciso como sentença sem mérito, sem o termo carência de ação, nos parece que a categoria condições da ação foi extinta do ordenamento brasileiro, incluindo legitimidade e interesse como pressupostos processuais. 44 BARBOSA MOREIRA, José Carlos. O novo processo civil brasileiro. 20. ed. Rio de Janeiro: Forense, 2000. p. $23 / 24$

45 A construção da petição inicial deve cumprir os requisitos tanto internos, da sua própria constituição, quanto aos externos, dos documentos essenciais. "Esta, que constitui o primeiro ato postulatório do processo, deve ser construída à luz do modelo estabelecido nos arts. 319 e 320 do CPC. Caso contrário, ou seja, se a petição inicial não estiver em termos para ser admitida, seja do ponto de vista lógico, seja sob o aspecto técnico, deverá ser indeferida.” TUCCI, José Roberto Cruz e. 
O primeiro dispositivo delineia os requisitos para a confecção da própria peça inicial, já no subsequente está a necessidade de que todos os documentos indispensáveis para a propositura da ação estejam anexados à petição inicial, bem como aqueles que o autor entenda como substancial para a demonstração dos fatos constitutivos do direito deste.

Na falta de algum dos requisitos da petição inicial atinentes ao art. 319 do CPC, é possível a correção, com a intimação para emenda da peça. Caso o autor permaneça em inércia ${ }^{46}$, haverá a extinção da demanda com o indeferimento da inicial. Mas, há a possibilidade de que haja um indeferimento parcial por descumprimento do art. 319 do CPC? Em determinados vícios não, como o endereçamento incorreto, a falta de informações das partes, pelo fato de que estes viciam a petição como um todo. Já a ausência de narrativa de questões de fato e os fundamentos jurídicos do pedido, o pedido com as suas especificações e o valor da causa seriam hipóteses que poderiam gerar uma extinção parcial, com o deferimento de parcela da inicial e o indeferimento de outra.

Sobre o art. 320, no tocante aos documentos indispensáveis e substanciais, somente a falta dos primeiros que ensejam um indeferimento da inicial, dependendo de cada espécie de demanda para que se possa ter a noção, ao certo, de qual serão os documentos indispensáveis. Por exemplo, numa ação de divórcio, a certidão de casamento é indispensável; numa ação de direito real, o registro do imóvel ou matrícula; etc.

Se a ausência de documento indispensável for sobre um dos pedidos somente e a demanda puder prosseguir em relação a outro pedido, sem afetar este pela ausência deste documento, há a possibilidade de indeferimento parcial da inicial, com a extinção igualmente parcial, o que gera uma decisão parcial sem mérito.

\subsection{A ausência de pressupostos de constituição e de desenvolvimento válido e regular do processo}

Se um processo estiver com ausência de pressupostos de constituição e de desenvolvimento válido e regular do processo pode ensejar a prolação de uma sentença sem o julgamento do mérito, meramente extintiva.

Os pressupostos ${ }^{47}$ de constituição e de desenvolvimento válido e regular do processo dividem-se entre aqueles de existência e de validade. Os de existência giram em torno de se ter um juízo, partes e uma demanda. Sem esses pressupostos sequer existirá um processo, com a necessidade de preenchimento destes. Todavia, para a extinção do processo diante dessa hipótese do art. 485, IV do CPC, a referência é a ausência de pressupostos de validade, que será a capacidade das partes, a petição apta e citação válida.

Comentários ao novo código de processo civil: artigos 485 ao 538. Coords: MARINONI, Luiz Guilherme; ARENHART, Sérgio Cruz; MITIDIERO, Daniel. São Paulo: Ed. RT, 2016. p. 38.

46 Sobre a necessidade do cumprimento dos requisitos da inicial e a possibilidade de emenda, diante da sanabilidade: "Destarte, o juiz, ao verificar que a petição inicial não preenche os requisitos dos arts. 319 e 320 , bem como os demais referidos, ou que apresenta defeitos e irregularidades capazes de dificultar o julgamento de mérito, determinará que o autor, no prazo de 15 (quinze) dias, a emende ou a complete, indicando com precisão o que deve ser corrigido ou completado, assim como preceitua o art. 321 do CPC. Caso não haja a referida emenda para corrigir ou completar aquilo que falta, o juiz indeferirá a petição inicial” THAMAY, Rennan Faria Kruger. Manual de direito processual civil. São Paulo: Saraiva, 2018. p. 263.

47 "A terminologia merece uma correção técnica. Pressuposto é aquilo que precede ao ato e se coloca como elemento indispensável para a sua existência jurídica; requisito é tudo quanto integra a estrutura do ato e diz respeito à sua validade. Assim, é mais técnico falar em requisitos de validade, em vez de "pressupostos de validade". Pressupostos processuais é denominação que se deveria reservar apenas aos pressupostos de existência (CARVALHO, 2005). Sucede que "pressupostos processuais" é expressão consagrada na doutrina, na lei (vide o inciso IV do art. 485 do CPC) e na jurisprudência. É possível, assim, falar em "pressupostos processuais" lato sensu, como locução que engloba tanto os requisitos de validade como os pressupostos processuais stricto sensu (somente aqueles concernentes à existência do processo).” DIDIER JR., Fredie. Comentários ao art. 485. In: CABRAL, Antônio do Passo; CRAMER, Ronaldo (Coord.). Comentários ao novo Código de Processo Civil. Rio de Janeiro: Forense, 2015. p. 679. 
A competência do juízo e imparcialidade do juiz também são pressupostos de validade, contudo não têm o condão de extinguir o processo, somente em dilatar a sua tramitação até a determinação correta da competência ou decisão sobre a imparcialidade do juiz, com ou sem a remessa a outro juiz.

Sobre a capacidade das partes, é importante que ambos os polos sejam dotados de capacidade processual, ou seja, a conjunção da capacidade de ser parte ${ }^{48}$, capacidade para estar em juízo ${ }^{49-50}$ e a capacidade postulatória ${ }^{51-52}$.

Esse é o ponto que detém maior atinência a essa hipótese de julgamento sem mérito, pela análise da capacidade da parte, em qualquer dos seus âmbitos. Caso uma das capacidades não esteja totalmente demonstrada, o juízo deve proporcionar o prazo para que haja a regularização da capacidade, como a juntada de uma documentação, a aferição de capacidade da parte, a procuração ad judicia ser específica, dentre outras possibilidades.

Se instado a manifestar-se sobre a capacidade das partes e o autor não providenciar a devida regularização ${ }^{53}$, o pressuposto da capacidade não será preenchido e o juízo deve prolatar uma sentença sem realizar o exame do mérito.

Se essa falta de capacidade atingir somente uma parte, poderá ser dada uma decisão parcial sem mérito? Esse é um ponto que merece uma análise detalhada, pelo fato de que se houver pluralidade de partes em um dos polos e um incapaz puder ser excluído, com o prosseguimento da demanda, tornando uma decisão parcial sem mérito, essa hipótese estaria mais próxima da exclusão de litisconsorte do que da própria ausência de capacidade, pelo fato de que se o direito a ser pleiteado for realmente dessa parte incapaz ou com vícios na demonstração de sua capacidade, dificilmente seria possível a cisão da lide e uma decisão parcial sem resolução do mérito.

Sobre a petição apta, a própria hipótese do art. 485, I do CPC, quando dispõe sobre a possibilidade do indeferimento da inicial versa sobre a verificação do pressuposto de validade do processo que é a petição inicial apta para proporcionar a instauração da demanda, o que já foi devidamente enfrentado em tópico próprio, com a possibilidade de decisão parcial sem resolução de mérito sobre indeferimento da petição inicial.

48 Sobre a capacidade processual: “capacidade de ser parte é a aptidão genérica para que se possa titularizar a pretensão à tutela jurídica. Assim, aquele ente que possui capacidade jurídica pode ser parte de uma relçaão jurídica processual (como autor, réu, terceiro interessado). Trata-se da qualificação subjetiva mínima necessariamente presente nos sujeitos da relação processual. (...) No Brasil, além de pessoas físicas e jurídicas, possuem capacidade de ser parte, entre outros, a sociedade não personificada, o espólio, a massa falida, o condomínio, o nascituro, o Ministério Público.” EXPÓSITO, Gabriela. A capacidade processual da pessoa com deficiência intelectual. Salvador: Juspodivm, 2019. p. 59.

49 Medina elucida que a capacidade processual "é a aptidão para praticar atos processuais independentemente de assistência e representação, pessoalmente, ou por outras pessoas apontadas pela lei.” MEDINA, José Miguel Garcia. Novo código de processo civil comentado. 2a . ed. São Paulo: Ed. RT, 2015. p. 83.

50 "A capacidade de estar em juízo, capacidade processual ou capacidade judiciária é a aptidão para a prática de atos processuais independentemente de representação de ou assistência.” EXPÓSITO, Gabriela. A capacidade processual da pessoa com deficiência intelectual. Salvador: Juspodivm, 2019. p. 63.

51 "a capacidade processual não se confunde com a capacidade postulatória, que é a aptidão que se tem para procurar em juízo.” NERY JR., Nelson; NERY, Rosa Maria de Andrade. Código de processo civil comentado. 11ª . ed., São Paulo: Ed. RT, 2010. p. 200.

52 "Possuem capacidade postulatória: os advogados, os estagiários, os membros do Ministério Público, o magistrado e em alguns casos as partes, como o credor de alimentos e as mulheres para formular a demanda das medidas protetivas de urgência que se alega vítima de violência doméstica e familiar. É importante observar que a capacidade postulatória é requisito de validade do processo em se tratando do autor da demanda. No caso do réu, a capacidade postulatória é apenas requisito de validade dos seus atos." EXPÓSITO, Gabriela. A capacidade processual da pessoa com deficiência intelectual. Salvador: Juspodivm, 2019. p. 63.

53 A sanabilidade deve ser sempre possibilitada ao autor: "o magistrado deverá determinar ao autor, no prazo de 15 dias, o suprimento do defeito, sob pena de indeferimento da inicial. Assim, se não for ele sanado, ou mesmo inviável a sua correção, o juiz não terá outra alternativa senão a de proferir o julgamento sem resolução do mérito.” TUCCI, José Roberto Cruz e. Comentários ao novo código de processo civil: artigos 485 ao 538. Coords: MARINONI, Luiz Guilherme; ARENHART, Sérgio Cruz; MITIDIERO, Daniel. São Paulo: Ed. RT, 2016. p. 49. 
Outro desenvolvimento válido e regular do processo seria a citação e a discussão sobre a sua validade ou não. A ausência de citação não poderia ser, a priori, empecilho que enseje uma sentença sem resolução de mérito, justamente pelo fato de que haverá a abertura para que o autor se manifeste sobre eventual dificuldade na realização da citação, contudo pode ser que na inércia do autor, o juízo prolate sentença extinguindo o processo. Mas, não seria possível, em regra, uma decisão parcial pela ausência de citação, somente se fosse para deixar de citar um dos réus, como a própria desistência do autor sobre a citação ou continuidade da demanda sobre aquele réu, o que também se confunde com exclusão de litisconsorte, o que é possível.

Essa questão prévia a ser analisada é uma questão de admissibilidade da própria demanda, sem o preenchimento de pressupostos de constituição ou regular desenvolvimento, com a necessidade de extinção do processo, com excepcionalidades sobre a possibilidade de prolação de uma decisão parcial sem resolução de mérito.

\subsection{A falta de interesse e legitimidade parcial}

Uma das análises que o juízo deve realizar será sobre o interesse processual do autor e a legitimidade das partes ${ }^{54}$ - tanto ativa quanto passiva.

Sobre o interesse processual, o autor deve preencher a possibilidade e a necessidade de intentar a demanda, com a demonstração do interesse na resolução daquele conflito ${ }^{55}$ sobre o qual existe uma pretensão resistida, desenvolvendo a impossibilidade de solução sem ser em juízo. A necessidade consiste na única resolução possível, com o vislumbre da saída ser pelo Judiciário, já a utilidade está na vinculação da possibilidade de chegar-se ao resultado prático jurídico pretendido pelo autor. Se o juízo entender que falta interesse, seja na forma de necessidade ou utilidade, pode indeferir a inicial, pela ausência deste.

Sobre a legitimidade das partes, o autor deve ser legítimo para o pleito do direito vindicado na demanda, bem como deve indicar um réu que seja igualmente legítimo ${ }^{56}$ para responder em juízo pelo objeto litigioso do processo. Se a parte, qualquer delas, em qualquer dos polos, for manifestadamente ilegítima, não guardando relação com a demanda ou com o objeto do processo, o juízo pode julgar pela extinção do processo.

54 Parte considerável da doutrina entende que a análise da legitimidade e interesse seria um aspecto próprio e autônomo aos pressupostos processuais, as condições da ação, com base na teoria eclética da ação, conforme a doutrina de Liebman. Todavia, com a retirada da impossibilidade jurídica do pedido e com a visão do CPC/2015 retirando termos como carência de ação, dentre outros, seria um viés de inserir a análise dentro de um binômio de cognição entre pressupostos e mérito. Para quem entende que ainda persiste (ou que sempre existiu) as condições da ação, a análise do interesse processual e legitimidade para a causa estariam num trinômio de cognição entre pressupostos processuais, condições da ação e mérito. Sobre essa divisão entre binômio e trinômio cognitivo: MUSSI, Breno Moreira. As condições da ação e a coisa julgada. Revista de Processo. Vol. 45, Ano 12, p. 35-53, São Paulo: Ed. RT, 1987; Sobre essa discussão, ainda no CPC/73, de existência ou não das condições da ação, dois textos antagônicos. Pela inexistência das condições da ação: DIDIER JR., Fredie. Um réquiem às condições da ação. Estudo analítico sobre a existência do instituto. Revista Forense. Rio de Janeiro, v. 351, p. 65-82, 2000; NOGUEIRA, Pedro Henrique. O juízo de admissibilidade do processo e as condições da ação: uma releitura a partir da teoria da ação de direito material. Revista Dialética de Direito Processual. Vol. 76, p. 93-105, 2009. Em sentido oposto, pela existência e resistência das condições da ação: CÂMARA, Alexandre Freitas. Será o fim da categoria 'condição da ação'? Uma resposta a Fredie Didier Júnior. Revista de Processo. Vol. 197, Ano 36, p. 261-269, São Paulo: Ed. RT. 2011. Sobre a retirada da impossibilidade jurídica do pedido como pressuposto processual ou uma das condições da ação: GOUVEIA, Lúcio Grassi de; PEREIRA, Mateus Costa; LUNA, Rafael. (Im)possibilidade jurídica: pedido (de)mérito; estudo de caso. Revista Brasileira de Direito Processual - RBDPro. v. 102, p. 299-316, 2018. A posição adotada neste estudo é que a divisão é num binômio cognitivo entre pressupostos processuais e mérito, com essas condições da ação outrora existentes inseridas como análise dos pressupostos, justamente pela inserção no art. 485 do CPC, apesar de entendimentos de que seriam o próprio mérito, o que também convergimos com o entendimento, contudo sem o CPC/2015 adotar tal critério.

55 Ou a necessidade da atividade jurisdicional sem necessariamente conter um conflito, como nas ações declaratórias ou de jurisdição voluntária.

56 Igualmente excepcionalizando nas hipóteses em que não há necessidade de réu, como na jurisdição voluntária. 
No entanto, em ambos os vícios de admissibilidade do processo, o juízo tem alguns momentos possíveis para que possa realizar tal análise: (i) no momento do deferimento ou indeferimento da inicial; (ii) ou, em momento posterior, a partir do saneamento; (iii) somente com a prolação da sentença.

No momento em que recebe a petição inicial ${ }^{57}$, o juízo deve analisar o preenchimento de todos os pressupostos processuais, contudo essa análise ainda é perfunctória, somente com a narrativa do autor e os documentos acostados com a inicial. Se, desde logo, o juízo perceber que falta interesse processual ou legitimidade - ativa ou passiva - deve indeferir a inicial. Evidentemente que essa análise, caso não seja possível essa percepção, não é definitiva, até por tratar-se de uma só narrativa, calcada nas alegações do autor constantes na inicial, o que pode importar numa aparência de preenchimento de ambos os pressupostos.

Todavia, a constatação de que falta interesse de agir ou legitimidade de qualquer das partes pode somente se configurar, claramente, para o juízo, em momento posterior ao da análise perfunctória da inicial, o que possibilita que o juízo reexamine tal ponto sobre o aspecto completo do processo, com as argumentações de ambos os lados, com a configuração de um processo em contraditório e que subsidie o juízo com informações pertinentes e completas.

Esse momento pode ser logo após a fase postulatória, no momento do saneamento e organização do processo, com a percepção diante do contraditório realizado pelas manifestações do réu, que não há interesse ou legitimidade do autor. Mas, se ainda não for possível, com a necessidade de dilação

$57 \quad$ O momento em que se pode analisar a presença ou não da legitimidade para a causa (tanto do autor, quanto do réu) ou do interesse processual varia, ocorrendo em diversos momentos do processo. Quando essas categorias eram vistas como condição da ação (ao menos pela maioria da doutrina, o que gera resquícios até hoje) tinha-se a dúvida sobre em qual momento e qual o grau de cognição que o juízo deveria ater-se para análise sobre a presença ou não das condições da ação (no CPC/73, interesse de agir, legitimidade para a causa e possibilidade jurídica do pedido). Para tanto, duas teorias se apresentavam sobre o momento e o modo de análise das condições da ação. A primeira teoria era sobre a apresentação, em qualquer momento em que se apresentar a possibilidade de análise sobre as condições da ação, se faltantes, seria consequente uma sentença sem mérito, ainda que fosse na fase de saneamento ou somente posterior à instrução. Por outro lado, na teoria da asserção, somente seria extinguiria um processo sem mérito por falta de condição da ação se a análise fosse pelas assertivas narradas pelo autor na inicial, se houvesse dúvidas e necessitasse de maior esclarecimentos ou instrução, a decisão sobre a carência de ação passaria a ser um julgamento de mérito. No CPC/2015 optou-se pela que não há condição de ação, mas a inclusão definitiva desses itens - interesse e legitimidade - como pressupostos processuais, com a inclusão na análise anterior ao mérito e a qualquer momento, adotando, portanto, uma tendência à teoria da apresentação, como pode ser feita ainda na inicial, indeferindo-a, no saneamento ou somente pós instrução, ainda assim, nos moldes do art. 485 do CPC, será uma sentença sem mérito. Por outro lado, Yarshell, Pereira e Rodrigues entendem que o CPC/2015 manteve a teoria da asserção, com a necessidade de continuarmos numa visão eclética da ação, explicando, para tanto, tal assertiva: “a chamada teoria da asserção procura dar uma solução às dificuldades que existem em se distinguir entre condições da ação e mérito. A teoria, que parte da premissa de que condição da ação e o mérito têm na relação de direito material um elemento comum, defende que a verificação das condições da ação em um determinado caso concreto deve ser promovida com fundamento nas afirmativas - ou asserções, daí o nome da teoria - feitas pelo autor na petição inicial, como se verdadeira fossem. A análise da presença das condições da ação, assim, deve ser promovida em cognição sumária, partindo-se das afirmações feitas na petição inicial. Se nesse momento for possível verificar a ausência de interesse processual ou legitimidade, deverá ser proferida sentença terminativa, que extinga o processo sem resolução de mérito. O julgamento realizado posteriormente a esse momento inicial de aferição das condições da ação em cognição sumária - promovida com base nos elementos de fato afirmados pelo autor na propositura da demanda -, que se baseie numa cognição mais ampla, seja pela ótica de sua extensão (levando em conta alegações do réu), seja pela ótica da profundidade (levando em conta elementos da prova trazidos posteriormente ao processo), será de mérito.” YARSHELL, Flávio Luiz; PEREIRA, Guilherme Setoguti J.; RODRIGUES, Viviane Siqueira. Comentários ao novo código de processo civil: artigos 334 ao 368. Coords: MARINONI, Luiz Guilherme; ARENHART, Sérgio Cruz; MITIDIERO, Daniel. São Paulo: Ed. RT, 2016. p. 147/148. Silva já tinha posição sobre a inexistência de tais condições da ação ainda no ordenamento revogado, contudo alinhava tais condições para serem tidas como mérito, o que acabou não contemplado pelo CPC/2015: "inexistente uma das 'condições da ação', ele está em verdade declarando a inexistência de uma pretensão acionável do autor contra o réu, estando, pois, a decidir a respeito da pretensão posta em causa pelo autor, para declarar que o agir deste contra o réu - não contra o Estado - é improcedente. E tal sentença é sentença de mérito. A suposição de que a rejeição da demanda por falta de alguma ‘condição da ação' não constitua decisão sobre a lide, não fazendo coisa julgada e não impedindo a reproposição da mesma ação, agora pelo verdadeiro legitimado ou contra o réu verdadeiro, parte do falso pressuposto de que a nova ação proposta por outra pessoa, ou pela mesma pessoa que propusera a primeira, agora contra outrem, seria a mesma ação que se frustrara no primeiro processo.” SILVA, Ovídio Baptista da. Curso de Processo Civil. 3ª . ed. Porto Alegre: Sérgio Antonio Fabris, 1996. p. 88. 
probatória, tanto para essa resolução quanto para o mérito, a definição sobre esses pontos fica postergada para a sentença, o que impede uma prolação de decisão parcial, nesse caso, em específico.

Nos primeiros casos - análise perfunctória da inicial ou saneamento e organização do processo - há a possibilidade de uma decisão parcial sem resolução de mérito, ou seja, uma decisão que extingua parcela do processo, seja pela ausência de interesse processual em somente um dos pedidos existentes, seja pela ilegitimidade de uma das partes para determinado pedido ou ponto do objeto litigioso do processo ou, ainda, que seja uma parte que possa ser excluída da lide, com a manutenção de outras partes.

Nessas possibilidades, pode-se prolatar uma decisão parcial sem resolução de mérito, com a continuidade do processo no tocante aos outros pontos em que as partes são legítimas ou que contenha interesse processual, caso o processo seja objetivamente complexo.

Especificadamente sobre a falta de interesse processual, não há como conter uma decisão parcial sem resolução de mérito com a extinção de parcela do processo se este for somente com um pedido. Há a possibilidade de uma decisão parcial quando houver cumulação de pedidos pelo autor e for constatada a falta de interesse processual em um dos pedidos, com a mantença, portanto, do processo quanto ao pedido - ou pedidos - sobressalentes.

Por outro lado, sobre a constatação de ilegitimidade de uma das partes existem duas hipóteses: (i) a ilegitimidade para um dos pedidos; (i) ou a ilegitimidade de uma das partes de um polo plúrimo.

No caso de uma demanda em que haja a constatação de que o autor ou o réu não são legitimados para aquele objeto litigioso do processo, a prolação deve ser de uma sentença sem resolução de mérito, caso o impacto seja na integralidade da demanda. No entanto, é possível de que essa ilegitimidade alcance somente um dos pedidos, o que geraria uma decisão parcial sem resolução de mérito, específica para declarar essa ausência de legitimidade daquela parte para determinada parcela da demanda, com o prosseguimento no restante em que há a constatação de legitimidade.

Por outro lado, há a possibilidade de constatar-se a ilegitimidade de uma das partes de um polo em que haja um litisconsórcio, gerando uma exclusão de litisconsorte, o que também é uma constatação de ilegitimidade ativa ou passiva.

Nesse ponto, ao declarar que determinada parte é ilegítima para prosseguir na lide, há uma decisão parcial sem resolução de mérito ${ }^{58}$, contudo, há, igualmente, a continuidade da tramitação processual sobre as partes que foram consideradas como legítimas para o prosseguimento da demanda.

\footnotetext{
58 A coisa julgada formada por essa decisão sem mérito, seja pela falta de interesse ou pela falta de legitimidade não permite a reproposição da mesma demanda, nos mesmos moldes, pelo fato de que o autor, numa futura demanda, ainda que somente sobre o que se decidiu parcialmente, deve corrigir o que foi declarado como equivocado, ou seja, deve intentar contra a parte correta, se foi ilegitimidade passiva ou deixar que o autor correto intente, se foi legitimidade ativa. $\mathrm{O}$ mesmo ocorre com o decidido sobre o interesse processual e sua ausência. Desse modo, a coisa julgada formada é meramente processual, contudo com a visão de que impede a reproposição da demanda. No entanto, Mourão soluciona a questão com a sua proposição a coisa julgada formal teria uma nova concepção, a qual certamente merece destaque, aduzindo "como a autoridade que torna indiscutível e imutável as decisões de conteúdo processual; coisa julgada material tornaria indiscutível e imutável decisões de mérito; coisa julgada formal e coisa julgada material projetam-se para fora do processo em que a decisão fora proferida; não haveria distinção entre elas; a distinção seria entre os respectivos objetos.” MOURÃO, Luiz Eduardo Ribeiro. Coisa julgada. Belo Horizonte: Fórum, 2006. p. 107/108. Nestes moldes, apesar de ser uma decisão parcial que ensejou um julgamento sem mérito, pelo fato de que o art. 485 do CPC assim visualiza, não permite a reproposição dessa parcela da demanda nos mesmos moldes: "a coisa julgada formal como uma situação jurídica que se caracteriza pela proibição de repetição, do exercício da mesma atividade jurisdicional, sobre decisão terminativa, pelas mesmas partes (e, excepcionalmente, por terceiros), em processos futuros (e nas fases do processo sincrético)." MOURÃO, Luiz Eduardo Ribeiro. As quatro espécies de coisa julgada no Novo CPC. Revista Brasileira de Direito Processual - RBDPro. Ano 26, nº. 101, p. 247-266, Belo Horizonte, jan/mar/2018. p. 257.
} 


\subsection{A perempção, a coisa julgada e litispendência parciais}

Nessa hipótese de sentença sem julgamento de mérito, os motivos são exatamente a ocorrência de um pressuposto negativo de admissibilidade pelo autor da demanda. Esses pressupostos trabalham em modo inverso do usual, com a necessidade de que não estejam presentes na demanda para que esta seja válida.

Ou seja, não poderá, nos moldes dos arts. 337 e 485 do CPC, uma demanda conter perempção, litispendência e coisa julgada. Se uma demanda contiver qualquer um destes institutos, a sentença de extinção será medida que se impõe, contudo se for somente imputada à parcela do processo, com o não enquadramento no restante da discussão material tida como objeto litigioso do processo, evidentemente que a extinção não alcançará a integralidade do processo, mas somente o que for impactado pelo pressuposto processual negativo, prolatando-se, consequencialmente, uma decisão parcial sem resolução de mérito ${ }^{59}$.

Para o exercício da jurisdição sobre um mesmo objeto, o art. 486, § 3ํ do CPC dispõe sobre a possibilidade do autor somente intentar por três vezes e se o autor der causa, nessas três vezes, a uma sentença fundada em abandono da causa ou outro motivo de extinção, não poderá propor nova ação contra o réu com o mesmo objeto, ficando-lhe ressalvada, entretanto, a possibilidade de alegar em defesa o seu direito.

Essa é a definição de perempção ${ }^{60}$.

Desse modo, se o mesmo autor intentar a mesma demanda por três vezes contra o réu e, em todas o resultado foi por um julgamento sem o exame de mérito, impossibilita que nova - uma quarta ação seja proposta pelo mesmo objeto, com mesmo pedido e causa de pedir. Se sobrevier esta quarta ação, a perempção estará visível e será um pressuposto processual negativo da admissibilidade a ser constatado e decidido, com a impossibilidade de continuidade do processo.

Evidentemente que a perempção se forma quando a terceira demanda foi julgada sem resolução de mérito, nascendo dali a impossibilidade de proposição de nova ação, não há necessidade da existência de eventual quarta ou mais ações para que haja a perempção. Todavia, se houver nova demanda, nesta conterá a perempção como pressuposto impeditivo, com a necessidade de prolação de uma sentença sem julgamento de mérito, justamente por perempção.

No entanto, se essa perempção impactar somente parcela dessa nova ação, o juízo deve prolatar uma decisão parcial sem resolução de mérito, com a extinção somente dos pontos materiais que são atingidos pela perempção existente e impossibilitados de serem discutidos nessa demanda, com a possibilidade de prosseguimento das outras parcelas materiais que contiverem outros objetos não impactados pela perempção.

Outro pressuposto negativo de admissibilidade do processo é a coisa julgada sobre o objeto de determinada demanda.

A conceituação de coisa julgada está no objeto da decisão realizada ao final do processo, seja uma sentença - em primeiro grau - ou um acórdão ou decisão unipessoal - em Tribunais, sem a interposição de recurso. Uma vez que se decida o objeto litigioso do processo - ou de um dos pedidos - e sobre

$59 \quad$ Sobre a possibilidade dos pressupostos processuais negativos inviabilizarem somente parcela da demanda: "Esses fenômenos podem ocorrer em relação a apenas parcela da demanda (litispendência parcial, por exemplo), nos casos de processo cumulativo (com mais de um pedido); nesse caso, não haverá extinção do processo, mas somente o juízo de inadmissibilidade da parcela em que se verificaram a perempção, a litispendência ou a coisa julgada, com o prosseguimento da causa para o julgamento da outra parcela. Mais um exemplo de decisão parcial, como se viu em item precedente." DIDIER JR., Fredie. Comentários ao art. 485. In: CABRAL, Antônio do Passo; CRAMER, Ronaldo (Coord.). Comentários ao novo Código de Processo Civil. Rio de Janeiro: Forense, 2015. p. 682.

60 Conceituando perempção: "Dá-se a perempção quando o autor der causa, por três vezes, à extinção do processo por abandono unilateral, caso em que não poderá ele propor novamente a mesma demanda, mas lhe sendo ressalvada a possibilidade de alegar seu direito como defesa (art. 486, § $3 \underline{o}$ ).” CÂAMARA. Alexandre Freitas. O novo processo civil brasileiro. 4ª . ed. São Paulo: Atlas, 2018. p. 264. 
essa decisão não houver a interposição ou cabimento de um recurso, com a ocorrência do trânsito em julgado, há a formação da coisa julgada ${ }^{61}$, com a imutabilidade daquela decisão, com a impossibilidade de discussão e nova decisão sobre aquele ponto ou objeto material.

$\mathrm{O}$ art. 502 do CPC conceitua a coisa julgada material pela autoridade que torna imutável e indiscutível a decisão de mérito não mais sujeita a recurso. Ou seja, não há a possibilidade de rediscutir matéria já discutida em processo que teve uma decisão com resolução de mérito transitada em julgado, no limites, como na dicção do art. 503 do CPC, da questão principal expressamente decidida.

Com a prolação de uma decisão com resolução de mérito em um processo e o seu trânsito em julgado, a imutabilidade alcança aquele conteúdo não podendo se discutir em outro processo entre as mesmas partes e a mesma matéria. Se houver uma nova demanda com essas identidades - partes e objeto, o juízo deve prolatar uma decisão sem o exame do mérito por ocorrência desse pressuposto processual negativa de admissibilidade do processo, extinguindo-a.

Numa próxima demanda, com pluralidade de objetos, com diferentes pedidos, se houver a identidade entre as partes - dessa demanda e daquela transitada em julgado - o juízo deve identificar qual o impacto da coisa julgada sobre o objeto e pedidos dessa demanda, com a prolação de uma decisão parcial sem resolução de mérito nos limites em que houver identidade entre as partes e o objeto desta atual demanda com aquela que transitou em julgado, com o prosseguimento processual da parcela daquilo que não é impactado pela coisa julgada.

A litispendência ${ }^{62}$ ocorre, conforme o art. $337, \S \S 2^{\circ}$ e $3^{\circ}$ do CPC, quando houver identidade entre duas demandas em curso, sendo as mesmas partes, a mesma causa de pedir e o mesmo pedido constante em ambas. Para que haja a litispendência precisa da constatação, oficiosa ou pelas partes, da conjunção dos quatro requisitos: demandas em curso; identidade de partes; causa de pedir; e pedido.

Se faltar algum desses pontos, não será litispendência.

Por exemplo, se forem as mesmas partes, causa de pedir ou pedido, mas com a comparação a uma demanda já transitada em julgado, o instituto muda para a coisa julgada. Se houver identidade de partes e causa de pedir, mas com pedido diverso, também não será litispendência e sim conexão. Logo, há a necessidade da conjunção de todos os requisitos para que seja litispendência entre duas demandas.

Dessa maneira, se existem dois processos com o mesmo objeto, evidentemente que não deve permanecer nesse estado de duplicidade, com a necessidade de que uma dos processos seja extinto, aquela que foi ajuizada em momento posterior, contudo se o preenchimento das identidades for somente parcial, a consequência será a redução do segundo processo para somente o pedido que não for repetido, com a extinção parcial daquele pedido litispendente ${ }^{63}$.

61 “Coisa julgada é, pois, a estabilidade da sentença irrecorrível." CÂMARA. Alexandre Freitas. O novo processo civil brasileiro. $4^{\mathrm{a}}$. ed. São Paulo: Atlas, 2018. p. 302.

62 Sobre o duplo significado do brocardo litispendência e a sua utilização de ambos os modos pelo CPC. "é equívoco, podendo significar pendência da causa (que começa a existir quando de sua propositura e se encerra com a sua extinção) ou pressuposto processual negativo verificado na concomitância de processos idênticos (mesma ação).” NEVES, Daniel Amorim Assumpção. Manual de direito processual civil. 8a . ed. Volume único. Salvador: Juspodivm, 2016. p. 492.

63 Nesse sentido de litispendência parcial: "É possível que haja litispendência parcial, quando a identidade se refere a apenas parcelas das demandas, em processos cumulativos. (...) A litispendência, nessa situação, é parcial e deve levar à inadmissibilidade do pedido deduzido em duplicidade, por litispendência.” YARSHELL, Flávio Luiz; PEREIRA, Guilherme Setoguti J.; RODRIGUES, Viviane Siqueira. Comentários ao novo código de processo civil: artigos 334 ao 368 . Coords: MARINONI, Luiz Guilherme; ARENHART, Sérgio Cruz; MITIDIERO, Daniel. São Paulo: Ed. RT, 2016. p. 136. 


\subsection{O reconhecimento parcial de convenção de arbitragem ou o reconhecimento pelo árbitro da sua competência parcial}

É aberto às partes a possibilidade de utilização do instituto da arbitragem para a solução de um conflito, diante da escolha por estas partes por uma jurisdição arbitral ${ }^{64} \mathrm{em}$ vez da possibilidade da jurisdição estatal.

As partes podem, em um contrato, estipular uma cláusula compromissória de arbitragem ou, posteriormente, um compromisso arbitral, ambos de maneira negocial dispondo que sobre o objeto ali negociado, a jurisdição e competência para a resolução de conflitos será do juízo arbitral, afastando a jurisdição estatal para o caso ${ }^{65}$.

Os requisitos necessários para essa convenção de arbitragem ser válida são: capacidade de ambas as partes; direitos patrimoniais; e a disponibilidade destes direitos.

Com a convenção de arbitragem estipulada, via contrato ou compromisso, para aquele objeto material, não há motivos para se intentar uma demanda, a priori, no Judiciário, pelo fato de que houve um consensual afastamento dessa esfera judicante, ao estipular a jurisdição e competência ao juízo arbitral.

No entanto, caso um dos convencionantes proponha uma demanda judicial contra a outra parte, sem mencionar a existência de uma convenção de arbitragem - seja cláusula compromissória ou compromisso arbitral, o juízo, sem ciência desse fato, recebe a demanda, dando-lhe devido andamento.

O réu, em sua peça contestatória ${ }^{66}$, pode alegar em preliminar a existência desse pressuposto processual negativo de convenção de arbitral - seja uma cláusula compromissória ou um compromisso arbitral - e, por este motivo, a impossibilidade do prosseguimento da demanda perante o juízo estatal. Ou seja, se as partes negociaram a jurisdição e competência, transferindo da judicial para a arbitral, o autor não deveria intentar tal demanda, uma vez que a resolução de conflitos, por causa do negócio jurídico processual realizado, será do juízo arbitral, afastando a jurisdição estatal para o caso ${ }^{67}$.

64 "Não deve, assim, haver dúvida de que o processo arbitral é jurisdicional, apesar de sua gênese contratual." YARSHELL, Flávio Luiz; PEREIRA, Guilherme Setoguti J.; RODRIGUES, Viviane Siqueira. Comentários ao novo código de processo civil: artigos 334 ao 368. Coords: MARINONI, Luiz Guilherme; ARENHART, Sérgio Cruz; MITIDIERO, Daniel. São Paulo: Ed. RT, 2016. p. 144.

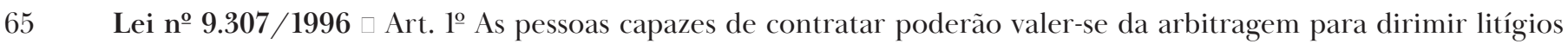
relativos a direitos patrimoniais disponíveis.

66 Rodovalho entende, acertadamente, que a convenção de arbitragem poderia ter até antes da contestação, em petição própria, sem preclusão para a contestação. É uma visão pragmática e correta, o que deve ter uma construção no dia a dia para a sua viabilidade. "A existência de convenção de arbitragem deveria ser deduzida em petição autônoma, na audiência de conciliação ou mediação, ou, caso essa não viesse a ocorrer, no momento em que o réu manifestasse desinteresse em sua realização, ou, ainda, no prazo da contestação, caso a audiência não tenha sido designada por outra razão. Em todas essas hipóteses, essa petição teria o efeito de interromper o prazo para contestar (desde que instruída com a convenção de arbitragem), que voltaria a correr, por inteiro, somente após a intimação da decisão que rejeitasse a alegação de convenção de arbitragem (evidentemente, pois, em caso de acolhimento, não haveria que se falar sequer em momento para contestar, com a extinção do processo sem resolução de mérito). Deste modo, evitar-se-ia que o réu fosse forçado a adiantar o mérito da matéria que pretendesse ver deduzida no juízo arbitral (meritum causae). Deveria ele apenas formular a petição autônoma, instruindo-a obrigatoriamente com o instrumento da convenção de arbitragem (sob pena de rejeição liminar, podendo, inclusive, vir a ser considerado revel, em caso de descumprimento dessa exigência), tecendo as razões que entendesse pertinentes, repita-se, apenas e tão somente com relação à competência do juízo arbitral, sem a necessidade de adentrar o mérito. O juiz, então, ouviria a parte contrária apenas quanto à alegação de convenção de arbitragem, decidindo a questão.” RODOVALHO, Thiago. CPC perdeu chance de colocar Brasil na vanguarda em processos com arbitragem. Disponível em: http: / / www.conjur.com.br /2016-mai-15/thiago-rodovalho-cpc-perdeu-chance-avancar-arbitragem-brasileira

67 Sobre a convenção de arbitragem versar sobre a afastabilidade da jurisdição e não de competência: STRECK, Lenio Luiz; GOUVEIA FILHO, Roberto Campos; Sousa, Diego Crevelin de. Por que o STJ deve rever a decisão sobre a taxatividade do artigo 1.015. https://www.conjur.com.br /2018-ago-13/stj-rever-decisao-taxatividade-11015?utm_source=dlvr.it\&utm_ medium $=$ facebook 
O autor, em outra hipótese, pode propor demanda judicial com a alegação inicial de invalidade da convenção de arbitragem, argumentando que houve vício na realização da convenção, seja via cláusula compromissória, seja via compromisso arbitral.

Em qualquer das alegações, uma vez a matéria alegada posta em juízo, este deve decidir a questão. Em primeiro momento de análise, deve ater-se a verificar se há existência formal ou não da referida convenção, bem como, após a possível existência, se, no plano de validade, esta produz efeitos jurídicos. Com isso, a decisão judicial tem duas hipóteses de resultado: (i) admitindo a convenção, com a prolação de uma sentença pela extinção do processo, sem julgamento do mérito; (ii) ou a rejeição da alegação de convenção de arbitragem, por inexistência ou invalidade de tal cláusula, com o prosseguimento do feito.

Outro meio de reconhecimento da jurisdição arbitral pode ser pela manifestação do próprio árbitro sobre a validade da convenção - qualquer delas - e sobre a jurisdição e competência daquele objeto. O novel ordenamento processual concedeu ao árbitro a competência sobreposta à do juízo estatal para declarar a sua própria competência. Se houver uma litispendência de demandas entre o juízo estatal e o arbitral, a decisão final será o do árbitro que detém a competência competência ${ }^{68}$ para o exame da validade da convenção de arbitragem.

A decisão do árbitro é a válida e o juízo estatal deve seguir o que for decidido pelo árbitro, seja pela validade da convenção, com a extinção do processo na esfera estatal, seja pela continuidade, quando a decisão for pela invalidade da convenção.

O juízo estatal está vinculado à decisão arbitral, nesse caso.

Evidentemente que sem a existência de uma demanda arbitral em concomitância à estatal, o juízo não deve aguardar pela decisão arbitral e, portanto, deve enfrentar a questão preliminar, o que gerará a continuidade ou extinção do processo.

Se nenhuma das partes, principalmente o réu, não realizar qualquer alegação sobre a existência de uma convenção de arbitragem - seja cláusula compromissória, seja compromisso arbitral - a matéria estará preclusa, deixando, portanto, de ser um pressuposto processual negativo de validade ${ }^{69}$, deixando de ser um motivo para que a demanda não prossiga.

No entanto, é possível que a convenção de arbitragem verse somente sobre parcela de um processo objetivamente complexo, com pluralidade de pedidos ou de partes, o que imporia, em caso de sobressalência da convenção de arbitragem, de uma extinção somente parcial, com o prosseguimento do processo no tocante aos outros pontos não convencionados, prolatando uma decisão parcial sem resolução de mérito.

\subsection{Homologar a desistência parcial da ação}

O autor pode desistir da demanda judicial que propôs.

A desistência da ação é um ato voluntário do autor que desiste da continuidade do processo e da pretensão ali existente. $\mathrm{O}$ ato de desistir do processo não se confunde com a desistência ao direito material, mas somente à continuidade daquele processo em específico.

$68 \quad$ No sentido da opção do CPC/2015, corretamente, atribuir a competência competência do árbitro: "para decidir a sua própria competência, resolvendo as impugnações que surjam acerca da sua capacidade de julgar, da extensão de seus poderes, da arbitrabilidade da controvérsia, enfim, avaliando a eficácia e a extensão dos poderes que as partes lhe conferiram tanto por via de cláusula compromissória, quanto por meio de compromisso arbitral.” CARMONA, Carlos Alberto. Arbitragem e processo. 3a . ed. São Paulo: Atlas, 2009. p. 175.

69 Nesse sentido, Dinamarco explica sobre a preclusão sobre arguição do pressuposto sobre a existência de convenção de arbitragem e a prorrogação da competência do juízo: "a convenção de arbitragem deixa de ser pressuposto (negativo) do julgamento do mérito sempre que ambas as partes renunciam a ela, o que é de absoluta compatibilidade com o instituto e associa-se à autonomia da vontade. (...) Essa renúncia pode ser explícita ou decorrer da propositura da demanda em juízo por uma das partes e a aceitação pela outra, sem invocar a convenção de arbitragem.” DINAMARCO, Cândido Rangel. Instituições de direito processual civil. Vol. III. 3a . ed. São Paulo: Malheiros, 2003. p. 196. 
O momento processual ${ }^{70} \mathrm{em}$ que o autor realiza esse ato voluntário tem pertinência, justamente para que se saiba o impacto, imediato ou não, que proporciona ao processo. Se realizado antes da citação válida, a desistência independe da manifestação ou aceite do réu, com o juízo devendo prolatar uma sentença de extinção do processo, sem julgamento de mérito, mesmo sem a ciência do réu.

Por outro lado, se o réu foi citado, validamente, apesar da manifestação de desistência do autor, o réu será instado a manifestar-se sobre tal ato voluntário, com a necessidade de anuência ${ }^{71}$. Nessa situação, com a anuência do réu, o juízo deve também prolatar uma sentença de extinção, sem julgamento do mérito, com a diferença pela condenação em honorários advocatícios ao advogado do réu e demais ônus sucumbenciais.

O autor, em um processo com pedidos cumulados, pode realizar o pleito pela desistência de uma parcela do processo, de um dos pedidos existentes na inicial, o que possibilita - antes da citação ou com a anuência do réu citado - a prolação de uma decisão parcial sem resolução de mérito, com a extinção somente daquela parcela do processo atinente ao pleito de desistência realizado pelo autor, com o prosseguimento em relação aos demais pedidos.

De igual maneira pode ser a desistência quanto a uma das partes de um litisconsórcio, como um pedido do próprio autor para que o réu fosse excluído, como na anuência do art. 338 e 339 da CPC sobre a ilegitimidade passiva ${ }^{72}$.

\subsection{Em caso de morte da parte, a ação for considerada intransmissível por disposição legal}

A hipótese do art. 485, IX do CPC determina que se o autor vier a óbito e o direito discutido na pretensão da demanda for intransmissível o processo será extinto, sem exame do mérito.

Essa intransmissibilidade deve ser por disposição legal.

A extinção do processo somente será possível com a composição em relação a morte do autor e a intransmissibilidade do direito discutido no processo, por disposição legal. Ou seja, a simples morte do autor não é motivo para a extinção do processo, com a necessidade da conjunção desta com a determinação legal sobre a intransmissibilidade daquele direito discutido no processo.

Nessa hipótese, diante de um processo complexo objetivamente, se a intransmissibilidade do direito versar sobre um dos pedidos do processo, este será extinto, com a possibilidade de prosseguimento de outros pedidos que, porventura, não forem intransmissíveis, sendo totalmente passível de uma decisão parcial sem mérito para extinção do direito que conjuga os requisitos da morte do autor e da intransmissibilidade do direito do objeto litigioso do processo.

70 "Em relação à desistência, o § 5.o deixa claro que essa providência pode ser adotada até a prolação da sentença, ressaltando-se que deve decorrer de manifestação expressa nesse sentido.” FREIRE, Alexandre; RAMOS NETO, Newton Pereira. Comentário ao art. 485. STRECK, Lenio. Comentários ao código de processo civil. 11ª ed. São Paulo: Saraiva, 2016. p. 700 .

71 Sobre a relativização da necessidade da anuência do réu, em caso de injustificação da continuidade da demanda: “Assim, deduzida a desistência após a apresentação da resposta, ocorrendo a recusa do réu, não há, em princípio, como ser homologada pelo juiz. Todavia, vislumbrada a ausência de fundamento da recusa e, assim, havendo mero capricho do réu, poderá ser perfeitamente indeferida a injustificada recursa oposta pelo demandando.” TUCCI, José Roberto Cruz e. Comentários ao novo código de processo civil: artigos 485 ao 538. Coords: MARINONI, Luiz Guilherme; ARENHART, Sérgio Cruz; MITIDIERO, Daniel. São Paulo: Ed. RT, 2016. p. 64/65.

72 No caso seria o reconhecimento da ilegitimidade de um dos réus, utilizando o art. 338 e 339 do CPC como base, como aqui explicado: "Substituição do réu: O Código inova quando, ao mesmo tempo em que retira a nomeação à autoria como figura interventiva, em afirmação à eficiência, possibilita, de forma ampla, a substituição do réu. Nos termos do art. 338, alegando o réu, na própria contestação (sem necessidade de petição autônoma), ser parte ilegítima ou não ser o responsável pelo prejuízo invocado, o juiz facultará ao autor, em 15 dias, a alteração da petição inicial para substituição do réu." MOUZALAS, Rinaldo. Comentários ao art. 338 e 339. Novo código de processo civil comentado - Tomo II (art. 318 ao art. 770). Orgs: RIBEIRO, Sergio Luiz Almeida; GOUVEIA FILHO, Roberto Pinheiro Campos; PANTALEÃO, Izabel Cristina; GOUVEIA, Lucio Grassi de. São Paulo: Lualri, 2017. p. 60. 


\section{Aspectos Conclusivos}

A processualidade brasileira trabalha, como uma busca pela simplicidade, para a construção procedimental de uma demanda simples, com uma relação jurídica a ser resolvida, diante de uma parte em cada polo.

Todavia, é possível, como analisado, uma complexidade objetiva do processo, com mais relações jurídicas a serem resolvidas na jurisdição, tanto em pluralidade de partes quanto em cumulação de pedidos.

Diante da complexidade objetiva do processo, o mérito do processo se divide em capítulos, com a divisão interna de uma sentença que enfrenta o mérito. Se a jurisdição pleiteada detém uma pluralidade de relações jurídicas, as respostas também serão plúrimas, cada qual com a sua admissibilidade, cada qual com os seus pressupostos processuais.

Logo, a divisão interna mínima entre capítulo de admissibilidade e de mérito de qualquer ação se desdobra a ser uma divisão admissibilidade/mérito em cada capítulo, não da jurisdição como um todo, mas de cada parcela dela.

Dessa maneira, há a possibilidade de uma cisão cognitiva por uma parcela da jurisdição não passar pela sua admissibilidade, contudo sem impactar a outra parcela da jurisdição que continuará em litispendência até a prolação da sentença.

A decisão parcial sem mérito é justamente essa manifestação do juízo como consequência da percepção da configuração dos requisitos autorizantes da prolação dessa decisão parcialmente extintiva.

Para tanto, cada pressuposto processual tem a sua própria questão de fato, sendo esta envolta no preenchimento ou não daquele pressuposto naquele capítulo da jurisdição. Essa questão de fato detém relação independente com as questões de fato do mérito. São pontos a serem considerados para que se analise o preenchimento do pressupostos processuais.

Dada a percepção que uma questão de fato demonstra que impossibilidade de prosseguimento daquela parcela da jurisdição, há o dever de utilizar-se do art. 354, parágrafo único do CPC.

Esse dispositivo é totalmente interligado e consequente a incidência de hipóteses constantes no art. 485 do CPC, aquelas da sentença sem mérito. O presente trabalho enfrentou todas essas possibilidades e o seu alcance para a prolação da decisão parcial sem mérito.

\section{Referências Bibliográficas}

ALVIM, Teresa Arruda; CONCEIÇÃO, Maria Lúcia Lins; RIBEIRO, Leonardo Ferres da Silva; MELLO, Rogério Licastro Torres de. Primeiros comentários ao novo código de processo civil. São Paulo: Ed. RT. 2015.

ARAÚJO, Luciano Vianna. Comentário ao art. 352. Novo código de processo civil comentado Tomo II (art. 318 ao art. 770). Orgs: RIBEIRO, Sergio Luiz Almeida; GOUVEIA FILHO, Roberto Pinheiro Campos; PANTALEÃO, Izabel Cristina; GOUVEIA, Lucio Grassi de. São Paulo: Lualri, 2017.

ARAÚJO, José Henrique Mouta. Comentário ao art. 354. Novo código de processo civil comentado - Tomo II (art. 318 ao art. 770). Orgs: RIBEIRO, Sergio Luiz Almeida; GOUVEIA FILHO, Roberto Pinheiro Campos; PANTALEÃO, Izabel Cristina; GOUVEIA, Lucio Grassi de. São Paulo: Lualri, 2017.

ASSIS, Araken de. Cumulação de ações. 4ª ed. São Paulo, Ed. RT, 2002.

AURELLI, Arlete. Comentário ao art. 337. STRECK, Lenio. Comentários ao código de processo civil. 11ㄹ. ed. São Paulo: Saraiva, 2016. 
Comentário ao art. 330. Novo código de processo civil comentado - Tomo II (art. 318 ao art. 770). Orgs: RIBEIRO, Sergio Luiz Almeida; GOUVEIA FILHO, Roberto Pinheiro Campos; PANTALEÃO, Izabel Cristina; GOUVEIA, Lucio Grassi de. São Paulo: Lualri, 2017.

BARBOSA MOREIRA, José Carlos. Questões prejudiciais e questões preliminares. Direito processual civil (ensaios e pareceres). Rio de Janeiro: Borsoi, 1971.

O novo processo civil brasileiro. $20^{\circ}$. ed. Rio de Janeiro: Forense, 2000.

BEDAQUE, José Rogério dos Santos. Os elementos objetivos da demanda examinados a luz do contraditório. Causa de Pedir e Pedido no processo civil (questões polêmicas). Coords: TUCCI, José Rogégio Cruz e; BEDAQUE, José Roberto dos Santos. São Paulo: Ed. RT, 2002.

CABRAL, Antonio do Passo. Contraditório como influência. Dicionário de Princípios Jurídicos. Flávio Galdino; Silvia Faber Torres; Ricardo Lobo Torres; Eduardo Takemi Kataoka. Editora: Elsevier - Campus. 2011.

CÂMARA, Alexandre Freitas. Será o fim da categoria ‘condição da ação'? Uma resposta a Fredie Didier Júnior. Revista de Processo. Vol. 197, Ano 36, p. 261-269, São Paulo: Ed. RT. 2011.

. O princípio da primazia da resolução do mérito e o novo código de processo civil. Revista de Direito da ADVOCEF. Ano XI nº 21, São Paulo: Advocef, nov/2015.

. O novo processo civil brasileiro. $4^{\mathrm{a}}$ ed. São Paulo: Atlas, 2018.

CARMONA, Carlos Alberto. Arbitragem e processo. 3ª ed. São Paulo: Atlas, 2009.

CARVAlHO, Milton Paulo de. Do pedido no processo civil. Porto Alegre: Sérgio Antonio Fabris, 1992.

DIDIER JR., Fredie. Um réquiem às condições da ação. Estudo analítico sobre a existência do instituto. Revista Forense. Rio de Janeiro, v. 351, p. 65-82, 2000.

Curso de direito processual civil: teoria geral do processo e processo de conhecimento. 17a. ed. Salvador: Juspodivm, 2015.

Comentários ao art. 485. In: CABRAL, Antônio do Passo; CRAMER, Ronaldo (Coord.). Comentários ao novo Código de Processo Civil. Rio de Janeiro: Forense, 2015.

DINAMARCO, Cândido Rangel. Capítulos de sentença. 3ª ed. São Paulo: Malheiros, 2008.

Instituições de direito processual civil. Vol. II 6ª ed. São Paulo: Malheiros, 2009.

EXPÓSITO, Gabriela. A capacidade processual da pessoa com deficiência intelectual. Salvador: Juspodivm, 2019.

FREIRE, Alexandre; RAMOS NETO, Newton Pereira. Comentário ao art. 485. STRECK, Lenio. Comentários ao código de processo civil. 11ª . ed. São Paulo: Saraiva, 2016.

GOUVEIA, Lúcio Grassi de; PEREIRA, Mateus Costa; LUNA, Rafael. (Im)possibilidade jurídica: pedido (de)mérito; estudo de caso. Revista Brasileira de Direito Processual - RBDPro. v. 102, p. 299-316, 2018.

MARQUES, José Frederico. Manual de direito processual civil. Vol. II, 2ª ed., Rio de Janeiro: Saraiva, 1976.

MEDINA, José Miguel Garcia. Novo código de processo civil comentado. $2^{\mathrm{a}}$ ed. São Paulo: Ed. RT, 2015.

MELLO, Marcos Bernardes de. Teoria do fato jurídico. 1 $^{\text {a }}$ ed. São Paulo: Saraiva, 2000.

MOURÃO, Luiz Eduardo Ribeiro. Coisa julgada. Belo Horizonte: Fórum, 2006.

MOURÃO, Luiz Eduardo Ribeiro. As quatro espécies de coisa julgada no Novo CPC. Revista

Brasileira de Direito Processual - RBDPro. Ano 26, n. 101, p. 247-266, Belo Horizonte, jan/ $\operatorname{mar} / 2018$. 
MOUZALAS, Rinaldo. Comentários ao art. 337 ao 339. Novo código de processo civil comentado - Tomo II (art. 318 ao art. 770). Orgs: RIBEIRO, Sergio Luiz Almeida; GOUVEIA FILHO, Roberto Pinheiro Campos; PANTALEÃO, Izabel Cristina; GOUVEIA, Lucio Grassi de. São Paulo: Lualri, 2017.

MUSSI, Breno Moreira. As condições da ação e a coisa julgada. Revista de Processo. Vol. 45, Ano 12, p. 35-53, São Paulo: Ed. RT, 1987.

NERY JR., Nelson; NERY, Rosa Maria de Andrade. Código de processo civil comentado. 11ª ed., São Paulo: Ed. RT, 2010.

NEVES, Daniel Amorim Assumpção. Manual de direito processual civil. 8a . ed. Volume único. Salvador: Juspodivm, 2016.

NOGUEIRA, Gláucia Assalin. O julgamento parcial: possibilidade de cisão do julgamento de mérito relativamente à parte incontroversa da demanda. São Paulo, SP, 2009. 191 p. Dissertação (Mestrado). Universidade de São Paulo. Programa de Pós-Graduação em Direito.

NOGUEIRA, Pedro Henrique. O juízo de admissibilidade do processo e as condições da ação: uma releitura a partir da teoria da ação de direito material. Revista Dialética de Direito Processual. Vol. 76, p. 93-105, 2009.

RODRIGUES, Raphael Silva. O novo código de processo civil e a exigência de fundamentação das decisões. Revista Dialética de Direito Processual. Vol. 153, p. 128-136, São Paulo: Dialética, $\operatorname{dez} / 2015$.

RODOVALHO, Thiago. CPC perdeu chance de colocar Brasil na vanguarda em processos com arbitragem. Disponível em: http://www.conjur.com.br/2016-mai-15/thiago-rodovalho-cpcperdeu-chance-avancar-arbitragem-brasileira

SCARPARO, Eduardo Kochenborger. Sentenças parciais? Considerações a partir de reforma do art. 162, §1º, do CPC. Revista de Processo. n. 148, Ano 32, p. 153-168, São Paulo: Ed. RT, Jun/2007.

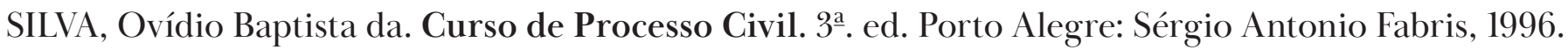

SOUZA, Paulo Roberto Pereira de. Abandono da causa. Revista de Processo. Vol. 24, Ano 6, p. 117-136, São Paulo: Ed. RT, Out/Dez/1981.

STRECK, Lenio Luiz; GOUVEIA FILHO, Roberto Campos; Sousa, Diego Crevelin de. Por que o STJ deve rever a decisão sobre a taxatividade do artigo 1.015. https://www.conjur.com.br/2018ago-13/stj-rever-decisao-taxatividade-11015?utm_source=dlvr.it\&utm_medium=facebook

THAMAY, Rennan Faria Kruger. Manual de direito processual civil. São Paulo: Saraiva, 2018.

TUCCI, José Rogério Cruz e. Abandono do processo. Revista de Processo. Vol. 52, Ano 13, p. 41-51. São Paulo: Ed. RT, Out/Dez/1988.

. Reflexões sobre a cumulação subsidiária de pedidos. Revista dos Tribunais (São Paulo). Vol. 786, p. 57-67, Abril/2001.

. A causa petendi no processo civil. 3a. ed. São Paulo: Ed. RT, 2009.

Garantia constitucional do contraditório no Projeto do CPC: Análise e Proposta. Revista Magister de Direito Civil e Processual Civil. Porto Alegre, ano VII, nº 38, 2010.

Comentários ao novo código de processo civil: artigos 485 ao 538. Coords: MARINONI, Luiz Guilherme; ARENHART, Sérgio Cruz; MITIDIERO, Daniel. 1ae ed., São Paulo: Ed. RT, 2016.

WAMBIER, Luiz Rodrigues; TALAMINI, Eduardo. Curso avançado de processo civil. vol. 2, $5^{\text {a }}$. ed. São Paulo: Ed. RT, 2016. 
YARSHELL, Flávio Luiz; PEREIRA, Guilherme Setoguti J.; RODRIGUES, Viviane Siqueira.

Comentários ao novo código de processo civil: artigos 334 ao 368. Coords: MARINONI, Luiz Guilherme; ARENHART, Sérgio Cruz; MITIDIERO, Daniel. São Paulo: Ed. RT, 2016. 